\title{
Dictyostelium discoideum as a Novel Host System to Study the Interaction between Phagocytes and Yeasts
}

\author{
Barbara Koller ${ }^{1}$, Christin Schramm ${ }^{1,2}$, Susann Siebert ${ }^{1}$, János Triebel ${ }^{1}$, Eric Deland ${ }^{1}$, \\ Anna M. Pfefferkorn ${ }^{1}$, Volker Rickerts ${ }^{2}$ and Sascha Thewes ${ }^{1 *}$ \\ ${ }^{1}$ Department of Biology, Chemistry, Pharmacy, Institute for Biology - Microbiology, Freie Universität Berlin, Berlin, Germany, \\ ${ }^{2}$ FG16, Robert Koch Institute, Berlin, Germany
}

OPEN ACCESS

Edited by:

Dominique Sanglard,

University of Lausanne, Switzerland

Reviewed by:

Joseph M. Bliss,

Women \& Infants Hospital of Rhode

Island, USA

Alejandro De Las Penas,

Instituto Potosino de Investigacion

Cientifica y Tecnologica, Mexico

${ }^{*}$ Correspondence:

Sascha Thewes

sascha.thewes@fu-berlin.de

Specialty section: This article was submitted to

Fungi and Their Interactions,

a section of the journal

Frontiers in Microbiology

Received: 26 September 2016 Accepted: 05 October 2016

Published: 21 October 2016

Citation:

Koller B, Schramm C, Siebert S, Triebel J, Deland E, Pfefferkorn AM,

Rickerts V and Thewes S (2016) Dictyostelium discoideum as a Novel Host System to Study the Interaction between Phagocytes and Yeasts.

Front. Microbiol. 7:1665.

doi: 10.3389/fmicb.2016.01665
The social amoeba Dictyostelium discoideum is a well-established model organism to study the interaction between bacteria and phagocytes. In contrast, research using $D$. discoideum as a host model for fungi is rare. We describe a comprehensive study, which uses $D$. discoideum as a host model system to investigate the interaction with apathogenic (Saccharomyces cerevisiae) and pathogenic (Candida sp.) yeast. We show that Dictyostelium can be co-cultivated with yeasts on solid media, offering a convenient test to study the interaction between fungi and phagocytes. We demonstrate that a number of $D$. discoideum mutants increase $\left(\right.$ atg $1^{-}$, kil1 $^{-}$, kil2 $\left.^{-}\right)$or decrease $\left(\operatorname{atg} 6^{-}\right)$the ability of the amoebae to predate yeast cells. On the yeast side, growth characteristics, reduced phagocytosis rate, as well as known virulence factors of $C$. albicans (EFG1, CPH1, HGC1, ICL1) contribute to the resistance of yeast cells against predation by the amoebae. Investigating haploid C. albicans strains, we suggest using the amoebae plate test for screening purposes after random mutagenesis. Finally, we discuss the potential of our adapted amoebae plate test to use $D$. discoideum for risk assessment of yeast strains.

Keywords: host-pathogen interaction, Saccharomyces, Candida, phagocytosis, virulence, autophagy, amoebae

\section{INTRODUCTION}

Since their first description in 1869 (Brefeld, 1869) social amoebae have become a model organism for several aspects, ranging from cell biology and developmental biology to molecular medicine (Müller-Taubenberger et al., 2013). Accordingly, the most-investigated species of the social amoebae, Dictyostelium discoideum, is one of the non-mammalian model organisms for biomedical research, as defined by the National Institutes of Health (USA; http://www.nih.gov/science/ models/). In the last 15 years $D$. discoideum has also been established as a host model to study the interaction with intracellular pathogenic bacteria like Legionella pneumophila, Mycobacterium marinum, and M. tuberculosis, Salmonella typhimurium, Pseudomonas aeruginosa, and others (for reviews see Clarke, 2010; Bozzaro and Eichinger, 2011). Subsequently, protocols have been established to study Dictyostelium-bacteria interactions (Froquet et al., 2009; Bozzaro, 2013; Tosetti et al., 2014).

However, to date, only few publications have investigated the interaction between Dictyostelium and fungi. It has been shown that co-incubation of D. discoideum with Cryptococcus neoformans enhances the virulence of the fungus in a mouse model of infection (Steenbergen et al., 2003), which might be explained by a capsule enlargement of $C$. neoformans during the co-incubation 
(Chrisman et al., 2011). Recently, the interaction of the filamentous fungus Aspergillus fumigatus with D. discoideum has been investigated (Hillmann et al., 2015). The authors found that known virulence determinants of $A$. fumigatus also protect against predation by Dictyostelium.

Research on the interaction between $D$. discoideum and yeasts is mainly focused on the investigation of phagocytosis processes of the amoeba (Rivero and Maniak, 2006). One reason why the interaction of amoebae and fungi is only poorly investigated might be the fact that protocols used to study bacteria failed when used for the investigation of fungi (Froquet et al., 2009). Nevertheless, since the genome of $D$. discoideum is fully sequenced (Eichinger et al., 2005) and D. discoideum is easy to cultivate and highly amenable to genetic manipulations (Fey et al., 2007; Gaudet et al., 2007), this amoebae would be an ideal phagocytic host to study interaction with yeasts. Therefore, we successfully adapted a protocol originally used to study the interaction between Acanthamoeba castellanii and $L$. pneumophila (Albers et al., 2005) for use with Dictyostelium and apathogenic yeasts (Saccharomyces cerevisiae) and the pathogenic yeasts Candida albicans and C. glabrata. We show that different yeast strains have differences in their resistance toward predation by $D$. discoideum. Pathogenic yeasts are usually resistant against predation. Finally, we investigated host factors as well as fungal factors that might have an influence on the interaction, and found that autophagy plays a crucial role in the part of the host D. discoideum.

\section{MATERIALS AND METHODS}

\section{Strains and Growth Conditions of Dictyostelia}

All $D$. discoideum strains used in this study are listed in Table $\mathbf{1 .}$ Strains were grown axenically in HL5 medium without glucose (ForMedium, Norfolk, UK) supplemented with $1.8 \%(\mathrm{w} / \mathrm{v})$ maltose (in the following referred to as "HL5") and $100 \mu \mathrm{g} / \mathrm{ml}$ ampicillin. For transgenic cell lines the medium was additionally supplemented with appropriate antibiotics $(20 \mu \mathrm{g} / \mathrm{ml}$ G418 or $5 \mu \mathrm{g} / \mathrm{ml}$ blasticidin). Cells were incubated on a rotary shaker at $22^{\circ} \mathrm{C}$ and $150 \mathrm{rpm}$ in the dark. Cell numbers were determined using a Neubauer counting chamber. For non-axenic growth, $E$. coli $\mathrm{B} / \mathrm{r}$ (Witkin, 1946) was grown overnight at $37^{\circ} \mathrm{C}$ and 200 $\mathrm{rpm}$ in LB-medium (10 g/l tryptone, $5 \mathrm{~g} / \mathrm{l}$ yeast extract, $10 \mathrm{~g} / \mathrm{l}$ $\mathrm{NaCl})$. The next day, the bacteria were washed twice with icecold SP-buffer ( $15 \mathrm{mM} \mathrm{KH}_{2} \mathrm{PO}_{4}, 2 \mathrm{mM} \mathrm{Na}_{2} \mathrm{HPO}_{4}, \mathrm{pH}$ 6.0) and cells were adjusted to $\mathrm{OD}_{600}=6$ in SP-buffer. Social amoebae listed in Table 2 were inoculated in the E. coli $\mathrm{B} / \mathrm{r}$ suspension and incubated on a rotary shaker with $150 \mathrm{rpm}$ at $22^{\circ} \mathrm{C}$ in the dark. For co-incubation studies with yeast, amoebae were washed free of bacteria twice with ice-cold SP-buffer by differential centrifugation at $800 \mathrm{~g}$ and were re-suspended in SP-buffer.

\section{Fungal Strains and Growth Conditions}

All S. cerevisiae and Candida strains used in this study are listed in Tables 3, 4. Yeast cells were grown in YPD-medium $(10 \mathrm{~g} / \mathrm{l}$ yeast extract, $10 \mathrm{~g} / \mathrm{l}$ peptone, $20 \mathrm{~g} / \mathrm{l}$ glucose) at $30^{\circ} \mathrm{C}$ and $180 \mathrm{rpm}$ on a rotary shaker. For the induction of flo1-expression in strain
KV210, galactose $[2 \%(\mathrm{w} / \mathrm{v})]$ was added to the YPD-medium. YPD-plates contained $2 \%(\mathrm{w} / \mathrm{v})$ agar. For flocculation analysis, yeast cells were grown overnight in YPD as described above. Five milliliter of the grown cultures were transferred to test tubes, carefully mixed, and incubated for $30 \mathrm{~min}$ without moving at room temperature. Sedimentation (= flocculation) of cells was monitored with a digital camera. Growth of yeasts in different media was determined photometrically at $600 \mathrm{~nm}$. Yeasts were grown either in YPD, HL5 without glucose supplemented with maltose ("HL5,") or HL5 without glucose and maltose (“AXoM") at $30^{\circ} \mathrm{C} . \mathrm{OD}_{600}$ was determined at the indicated time points.

\section{Amoebae Plate Test}

The amoebae plate test (Figure 1) was adapted from Albers et al. (2005). Amoebae were grown to mid-logarithmic phase $\left(4-8 \times 10^{6}\right.$ cells $\left./ \mathrm{ml}\right)$, washed once with SP-buffer and adjusted to $8 \times 10^{6}$ cells $/ \mathrm{ml}$ in SP. Five milliliter of the suspension were spread on solid HL5 agar [2\% (w/v)] in $\varnothing 9 \mathrm{~cm}$ petri dishes. After $30 \mathrm{~min}$ the supernatant was aspirated and plates were incubated overnight at $22^{\circ} \mathrm{C}$. To test non-axenically grown amoebae, HL5 agar plates were supplemented with ampicillin $(100 \mu \mathrm{g} / \mathrm{ml})$ and streptomycin $(50 \mu \mathrm{g} / \mathrm{ml})$ to prevent growth of residual bacteria. The next day, yeast cells grown overnight in YPD at $30^{\circ} \mathrm{C}$ were washed twice with SP, counted, and adjusted to $2 \times 10^{8}$ cells $/ \mathrm{ml}$ in SP. Flocculating yeasts were additionally washed before counting in $250 \mathrm{mM}$ EDTA to dissociate cells from flocs. The yeast suspensions were serially diluted 1:10 in SP $\left(2 \times 10^{7}-2 \times 10^{4}\right.$ cells $\left./ \mathrm{ml}\right)$ and $5 \mu$ l of each dilution were spotted on the amoeba plates and on plates without amoebae (control), respectively. Control plates for non-axenically grown amoebae were supplemented with ampicillin and streptomycin. Plates were incubated at $22^{\circ} \mathrm{C}$. Documentation was done at the indicated time points. Amoebae plate tests were repeated at least three times (biological replicates) per strain.

\section{Quantitative Co-incubation}

To quantify the effects of the co-incubation of Dictyostelium with yeast cells, amoebae from mid-logarithmic growth phase were washed twice with ice-cold SP and adjusted to $3.3 \times 10^{5}$ cells $/ \mathrm{ml}$ in AXoM. Amoebae were seeded in flat-bottomed 96-well plates (150 $\mu \mathrm{l} /$ well). Yeast cells were grown overnight in YPD, washed twice in SP, and adjusted to $2 \times 10^{6}$ cells $/ \mathrm{ml}$ in SP. Serial 1:4 dilutions were prepared in SP down to $1.95 \times 10^{3}$ cells $/ \mathrm{ml}$. Fifty microliters of each dilution were added to the amoebae in triplicate, resulting in multiplicity of infections (MOI) of 2, $0.5,0.125,0.03125,0.00781,0.00195$, respectively. As a control, yeast cells were inoculated in triplicate in $150 \mu \mathrm{l} \mathrm{AXoM}$ without amoebae. Plates were incubated at $22^{\circ} \mathrm{C}$. At the indicated time points amoebae were lysed by adding $5 \mu \mathrm{l}$ Triton X-100 (20\%) and yeast cells were dissociated by adding $50 \mu$ l EDTA $(250 \mathrm{mM})$. After appropriate dilution, yeast cells were spread on YPD-plates, incubated at $30^{\circ} \mathrm{C}$, and colony-forming units (cfu) were counted. Triton X-100 and EDTA had no effect on the survival of yeast cells in our assay (data not shown). Co-incubation was repeated for each strain three times (biological replicates) including three technical replicates. 
TABLE 1 | Dictyostelium discoideum strains used in this study.

\begin{tabular}{|c|c|c|c|}
\hline Strain & Genotype & Parental strain & References \\
\hline AX2 & axeA2, axeB2, axeC2 & NC4 & Watts and Ashworth, 1970 \\
\hline $\mathrm{DH} 1$ & axeA1, axeB1, axeC1, pyr5-6-[pRG24], ura- & NC4 & Caterina et al., 1994 \\
\hline $\operatorname{atg} 1^{-}$ & axeA1, axeB1, axeC1, atg1-1[pAtg1-1], bsR & $\mathrm{DH} 1$ & Otto et al., 2004 \\
\hline $\operatorname{atg} 5^{-}$ & axeA1, axeB1, axeC1, pyr5-6-[pRG24], ura-, atg5-[atg5-KO], bsR & $\mathrm{DH} 1$ & Otto et al., 2003 \\
\hline $\operatorname{atg}^{-}$ & axeA1, axeB1, axeC1, pyr5-6-[pRG24], ura-, atg6-[atg6-HR], bsR & $\mathrm{DH} 1$ & Otto et al., 2004 \\
\hline $\operatorname{atg} 7^{-}$ & axeA1, axeB1, axeC1, pyr5-6-[pRG24], ura-, atg7-[atg7-KO], bsR & $\mathrm{DH} 1$ & Otto et al., 2003 \\
\hline $\operatorname{atg} 8^{-}$ & axeA1, axeB1, axeC1, pyr5-6-[pRG24], ura-, atg8-[atg8-KO], bsR & $\mathrm{DH} 1$ & Otto et al., 2004 \\
\hline CNA-RNAi & axeA2, axeB2, axeC2, [canA-RNAi], neoR & AX2 & Thewes et al., 2014 \\
\hline CNB-RNAi & axeA2, axeB2, axeC2, [cnbA-RNAi], neoR & AX2 & Boeckeler et al., 2006 \\
\hline$d y m A^{-}$ & axeA2, axeB2, axeC2, dymA-, bsR & AX2 & Wienke et al., 1999 \\
\hline kil1- & axeA1, axeB1, axeC1, pyr5-6-[pRG24], ura-, kil1-[kil1-bsr], bsR & $\mathrm{DH} 1$ & Benghezal et al., 2006 \\
\hline kil2- & axeA1, axeB1, axeC1, pyr5-6- [pRG24], ura-, kil2-, [kil2-bsr], bsr & $\mathrm{DH} 1$ & Lelong et al., 2011 \\
\hline phg1A- & axeA1, axeB1, axeC1, pyr5-6-[pRG24], ura-, phg1a-[pPHG1a], bsR & $\mathrm{DH} 1$ & Cornillon et al., 2000 \\
\hline $\mathrm{racH}^{-}$ & axeA2, axeB2, axeC2, racH::BSR & AX2 & Somesh et al., 2006 \\
\hline$r d e A^{-}$ & axeA1, axeB1, axeC1, pyr5-6-[pRG24], rdeA-[pDIV5], ura+ & $\mathrm{DH} 1$ & Chang et al., 1998 \\
\hline $\operatorname{sib} A^{-}$ & axeA1, axeB1, axeC1, pyr5-6-[pRG24), sibA-, ura+ & $\mathrm{DH} 1$ & Cornillon et al., 2006 \\
\hline$w s h A^{-}$ & axeA2, axeB2, axeC2, wshA-[wshA::bsr], bsR & $\mathrm{AX} 2$ & Carnell et al., 2011 \\
\hline
\end{tabular}

All strains were grown axenically.

TABLE 2 | Non-axenic social amoebae used in this study.

\begin{tabular}{|c|c|c|}
\hline Species & Strain & References \\
\hline Dictyostelium caveatum & BW1 (ATCC66413) & ATCC \\
\hline Dictyostelium polycephalum & natural isolate & T. Winckler (Jena, Germany) \\
\hline Dictyostelium purpureum & natural isolate & T. Winckler (Jena, Germany) \\
\hline Polysphondylium pallidum & PN500 & Francis, 1975 \\
\hline
\end{tabular}

All strains were grown in association with Escherichia coli B/r.

\section{Trypan Blue Exclusion Assay}

Survival of the amoebae was investigated using the trypan blue exclusion assay. D. discoideum AX2 was grown in HL5 at $22^{\circ} \mathrm{C}$ to mid-log phase, washed twice with SP-buffer and $900 \mu \mathrm{l}$ of cells in SP were seeded in triplicate with a density of $1.3 \times 10^{5}$ cells/ml in 24-well plates containing sterile, acid-washed glass coverslips $(\varnothing 14 \mathrm{~mm})$. Yeast cells were grown overnight at $30^{\circ} \mathrm{C}$ in YPD, washed twice with SP and $100 \mu$ l yeast suspension in SP $\left(2.4 \times 10^{6}\right.$ cells $\left./ \mathrm{ml}\right)$ was added to the amoebae to a final MOI of 2. Plates were incubated at $22^{\circ} \mathrm{C}$. At the indicated time points the coverslips were carefully removed from the wells and adhering cells were stained with trypan blue (1\% in SP) and directly analyzed under the microscope. Blue D. discoideum cells were counted as dead cells, whereas unstained cells were counted as living cells. At least 50 cells were counted per well. As a control D. discoideum cells were incubated in SP-buffer without yeast. Experiments were repeated three times (biological replicates).

\section{Phagocytosis Assay}

Uptake of yeast cells by the amoebae was quantified microscopically. Yeast strains were grown overnight at $30^{\circ} \mathrm{C}$ in YPD, washed twice with SP-buffer, and re-suspended in
SP-buffer at $1 \times 10^{8}$ cells $/ \mathrm{ml}$. D. discoideum strains were grown to mid-log phase in HL5 at $22^{\circ} \mathrm{C}$, washed twice in SP buffer, and re-suspended in $10 \mathrm{ml} \mathrm{AXoM}$ in a $100 \mathrm{ml}$ Erlenmeyer-flask at $1 \times$ $10^{6}$ cells $/ \mathrm{ml}$. Three hundred microliters of the yeast suspension were added to reach an MOI of 3 . The preparations were incubated at $22^{\circ} \mathrm{C}$ on a rotary shaker at $70 \mathrm{rpm}$. At the indicated time points $1 \mathrm{ml}$ of the yeast/amoeba mixture was withdrawn from the flask, washed twice with SP-buffer and re-suspended in $500 \mu \mathrm{l} \mathrm{SP}$ containing $0.01 \%$ calcofluor white. Cells were incubated for $5 \mathrm{~min}$ at room temperature, washed once with SP buffer and re-suspended again in $500 \mu \mathrm{l} \mathrm{SP}$. Phagocytized yeast cells were distinguished from non-phagocytized yeast cells due to the co-localization with amoebae with simultaneous absence of calcufluor staining. Only non-phagocytized cells showed fluorescence using a DAPI-filter (excitation wavelength $460 \mathrm{~nm}$ ) with the Nikon ECLIPSE 90i fluorescence microscope (Nikon, Düsseldorf, Germany). Uptake of yeast cells by amoebae was calculated according to McKenzie et al. (2010). Phagocytosis experiments were repeated for each strain three times (biological replicates).

\section{Time-Lapse Microscopy}

The interaction of yeast cells and amoebae was documented for $4-5 \mathrm{~h}$ in submerged culture using time-lapse microscopy. $D$. discoideum AX2 cells grown to mid-logarithmic phase in HL5 were washed once with ice-cold SP-buffer and cell pellets were re-suspended in AXoM at a density of $1.3 \times 10^{6}$ cells $/ \mathrm{ml}$. Five hundred microliters were spread in 24-well plates. Yeast cells were grown overnight in YPD, washed twice with SP-buffer, and cells were re-suspended in AXoM at a density of $2 \times 10^{7}$ cells $/ \mathrm{ml}$. One hundred microliters of the yeast cell suspension were added to the amoebae in 24-well plates to reach an MOI of 3. Interaction of cells was observed at $22^{\circ} \mathrm{C}$ using the Axiovert 
TABLE 3 | Saccharomyces cerevisiae strains used in this study.

\begin{tabular}{|c|c|c|}
\hline Strain & Genotype & References \\
\hline RKI 05-0082-01 & Wild type (bloodstream isolate) & Robert Koch Institute, Berlin, Germany \\
\hline RKI 05-0082-02 & Wild type (bloodstream isolate) & Robert Koch Institute, Berlin, Germany \\
\hline RKI 07-0060 & Wild type (bloodstream isolate) & Robert Koch Institute, Berlin, Germany \\
\hline RKI 07-0061 & Wild type (bloodstream isolate) & Robert Koch Institute, Berlin, Germany \\
\hline Baker's yeast & Wild type (bakery isolate) & Local bakery, Berlin, Germany \\
\hline Brewer's yeast & Wild type (brewery isolate) & Versuchs- und Lehranstalt für Brauerei, Berlin, Germany \\
\hline BY25558 & MATa ura3 $\triangle 0$ URA3-TDH3p-FLO1 & Nonklang et al., 2009 \\
\hline BY25559 & MATa ura3 $\triangle 0$ URA3-TDH3p-FLO5 & Nonklang et al., 2009 \\
\hline BY25560 & MATa ura3 $\triangle 0$ URA3-TDHЗp-FLO9 & Nonklang et al., 2009 \\
\hline BY25561 & MATa ura3 $\triangle 0$ URA3-TDHЗp-FLO10 & Nonklang et al., 2009 \\
\hline BY4741 & MATa his $3 \Delta 1$ leu2 $\Delta 0$ lys $2 \Delta 0$ ura3 $\Delta 0$ & Purevdorj-Gage et al., 2007 \\
\hline INVSc1 & MATa his3 $\Delta 1$ leu2 trp1-289 ura3-52 & Life Technologies, Darmstadt, Germany \\
\hline KV210 & MATa his3 $\Delta 1$ leu2 $\Delta 0$ lys $2 \Delta 0$ ura3 $\Delta 0$ Galp-FLO1 & Smukalla et al., 2008 \\
\hline KV22 & MATa his3 $\Delta 1$ leu2 $\Delta 0$ lys $2 \Delta 0$ ura3 $\Delta 0$ flo $1:: K A N M X$ & Smukalla et al., 2008 \\
\hline KV84 & Wildtype (natural flocculation) & Beauvais et al., 2009 \\
\hline $\mathrm{TH} 2-1 \mathrm{~B}$ & MATa SUC2 mal mel gal2 CUP1 mnn1 mnn2 & Clarke, 2010 \\
\hline w303a & MATa leu2-3,112 trp1-1 can1-100 ura3-1 ade2-1 his3-11,15 & Wallis et al., 1989 \\
\hline$w 303 a / \alpha$ & $\begin{array}{l}\text { MATa/ } \alpha \text { leu2-3,112 trp1-1 can1-100 ura3-1 ade2-1 } \\
\text { his3-11,15 }\end{array}$ & Wallis et al., 1989 \\
\hline w303 $\alpha$ & MAT $\alpha$ leu2-3,112 trp1-1 can1-100 ura3-1 ade2-1 his3-11,15 & Wallis et al., 1989 \\
\hline Y-187 & $\begin{array}{l}\text { MATa gal4 gal80 his3 trpl-901 ade2-101 ura3-52 leu2-3,-112 } \\
\text { URA3 GAL->lacZ } \text { met }^{-}\end{array}$ & Harper et al., 1993 \\
\hline Y-190 & $\begin{array}{l}\text { MATa leu2-3,112 ura3-52 trp1-901 his3- } \Delta 200 \text { ade2-101 } \\
\text { gal4 } \Delta \text { gal80 } \Delta \text { URA3 GAL-lacZ, LYS GAL-HIS3, cyh }\end{array}$ & Harper et al., 1993 \\
\hline
\end{tabular}

25 microscope with a 20x objective (Carl Zeiss, Jena, Germany). The microscope was equipped with a TCA-3.0 camera (Tuscen Photonics, Fuzhou, China) and pictures were taken using the Micam 2.0 software (Marie van Westen, Groningen, Netherlands; http://www.science4all.nl) with the following settings: capture interval $1 \mathrm{~min}$, total number of frames 240-300, playback 10 frames/s without compression.

\section{Analysis of Hyphae Formation}

To test for the ability of C. albicans strains to form hyphae during co-incubation with the amoebae, mid-log D. discoideum AX2 cells grown in HL5 were washed twice with SP buffer and were re-suspended in AXoM at $3.3 \times 10^{5}$ cells $/ \mathrm{ml}$. One hundred and fifty microliters of the Dictyostelium suspension was applied to 96-well plates and $50 \mu \mathrm{l}$ of SP-washed yeast cells (grown in YPD overnight at $30^{\circ} \mathrm{C}$ ) were added with an MOI of 0.125 . Plates were incubated at $22^{\circ} \mathrm{C}$ in the dark and pictures were taken at the indicated time points using the Axioskop 2 microscope (Zeiss, Jena, Germany).

To test whether cell-cell-contact is necessary for hyphae formation, amoebae, and yeast cells were separated using Transwell ${ }^{\circledR}$ inserts (HTS Transwell ${ }^{\circledR}-24$, PET membrane, pore size $0.4 \mu \mathrm{m}$; Corning Incorporation, New York, USA). C. albicans strains were grown overnight in YPD at $30^{\circ} \mathrm{C}$ and washed twice with SP buffer. Washed cells were re-suspended in AXoM at 1.7 $\times 10^{6}$ cells $/ \mathrm{ml}$. Cells $(600 \mu \mathrm{l})$ were seeded into 24 -well plates (lower compartment). Transwell ${ }^{\circledR}$ inserts (upper compartment) were inserted and filled with $100 \mu \mathrm{l}$ of $D$. discoideum cells $(6.8 \times$ $10^{6}$ cells $/ \mathrm{ml}$ in AXoM), $100 \mu \mathrm{l}$ D. discoideum cells together with $10^{5}$ C. albicans cells, or $100 \mu \mathrm{l}$ of $D$. discoideum cells lysed with $25 \mu \mathrm{l}$ Triton X-100 (20\%), respectively. As a control, C. albicans cells were treated with $25 \mu \mathrm{l}$ Triton X-100. Plates were incubated at $22^{\circ} \mathrm{C}$ and pictures were taken after $48 \mathrm{~h}$.

Hyphae formation was further investigated with culture supernatant and treated lysate. Culture supernatant was taken from stationary phase $D$. discoideum cell cultures $\left(1-2 \times 10^{7}\right.$ cells/ml) after centrifugation at $400 \mathrm{~g}$ for $5 \mathrm{~min}$. Cell lysate was prepared by lysing $D$. discoideum cells from mid-log phase with Triton X-100 (see above). Lysate was incubated for $1 \mathrm{~h}$ at $4^{\circ} \mathrm{C}$ or $-20^{\circ} \mathrm{C}$, or it was boiled for $5 \mathrm{~min}$ at $95^{\circ} \mathrm{C}$. Additionally, cell lysate was centrifuged at room temperature at $500 \mathrm{~g}$ and $5000 \mathrm{~g}$, respectively. One hundred microliters of the supernatant or lysate were added to $1 \times 10^{5} \mathrm{C}$. albicans cells in 24 -well plates. Plates were incubated at $22^{\circ} \mathrm{C}$ and pictures were taken after $48 \mathrm{~h}$. All experiments were repeated three times (biological replicates).

\section{Propidium lodide Staining and Flow Cytometry}

To test whether the haploid C. albicans strains are still haploid, cells were stained with propidium iodide (PI) and analyzed by flow cytometry. Yeast cells were grown to mid-logarithmic growth phase at $30^{\circ} \mathrm{C}$ and $5 \times 10^{6}$ cells were centrifuged at 2000 rpm for $5 \mathrm{~min}$. The supernatant was discarded and the cell pellet was fixed in $1 \mathrm{ml}$ ice-cold $70 \%$ ethanol. One hundred and fifty 
TABLE 4 | Candida strains used in this study.

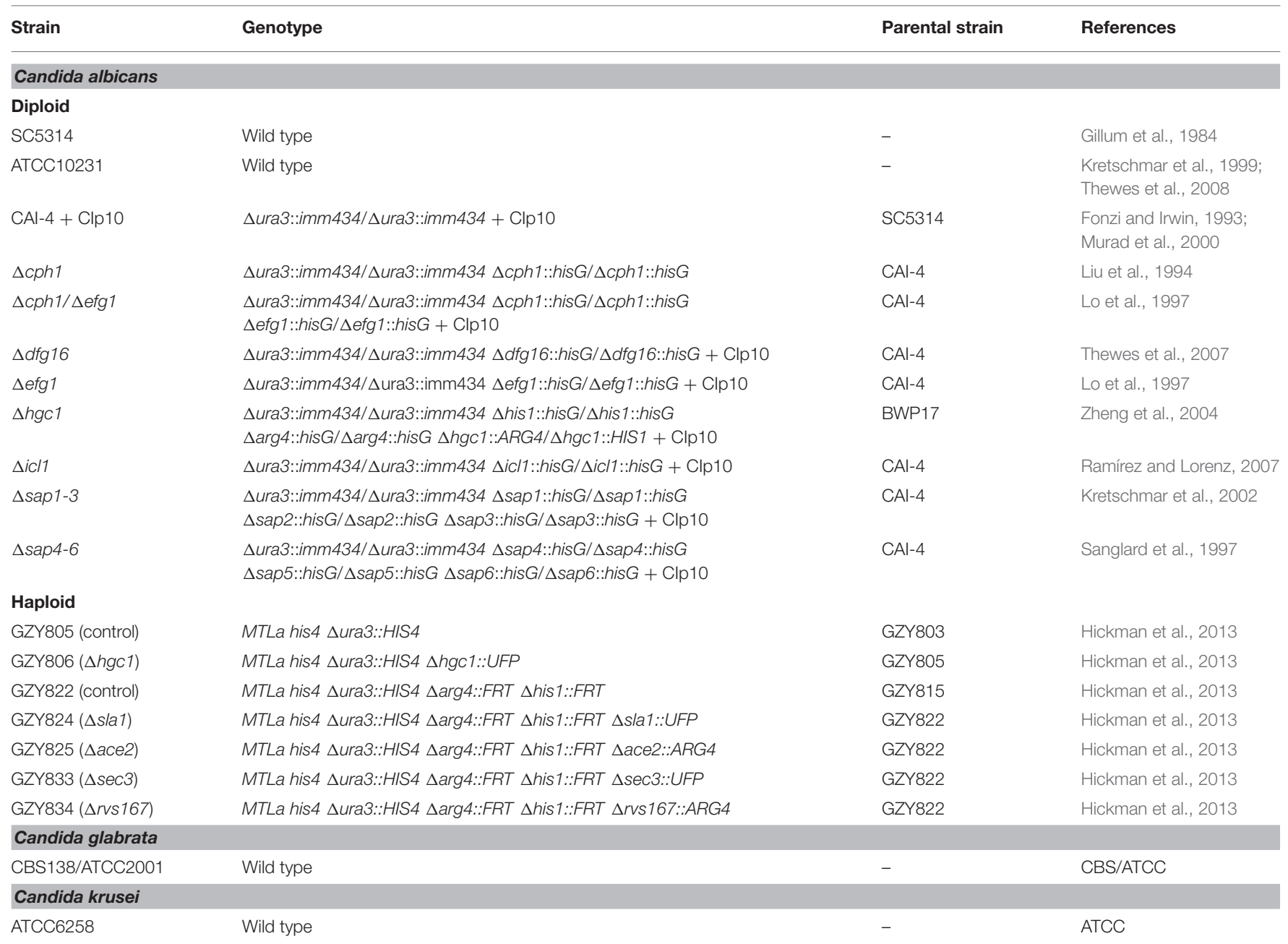

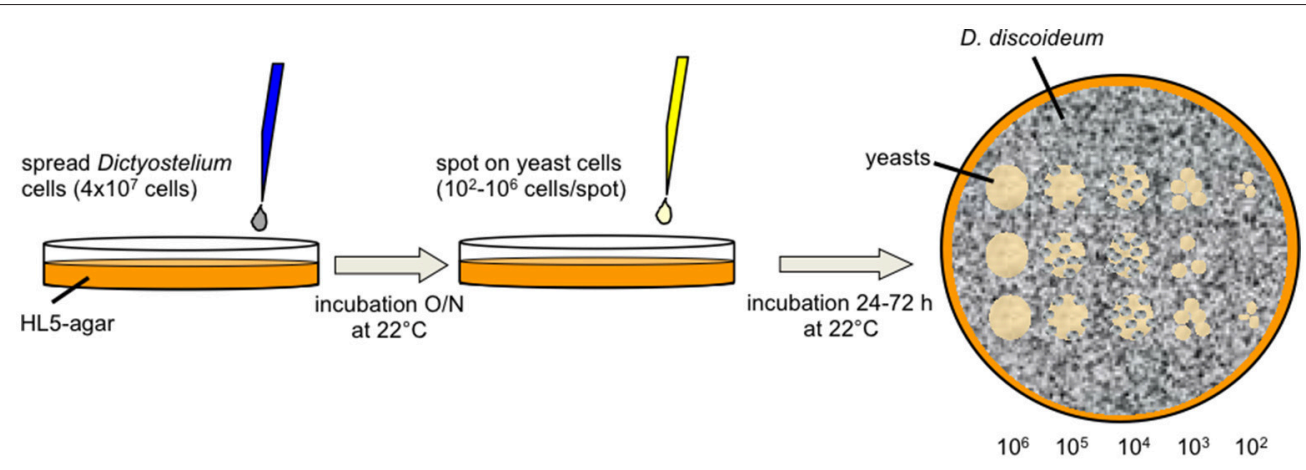

FIGURE 1 | Diagram of the amoebae plate test. D. discoideum cells were spread on HL5-agar. After incubation overnight, serial dilutions of yeast cells were spotted on the surface. Co-incubation of amoebae and yeast cells was observed up to $72 \mathrm{~h}$ after spotting the yeasts.

microliters of fixed cells (approximately $2-3 \times 10^{6}$ cells) were mixed with $1.5 \mathrm{ml} 50 \mathrm{mM}$ sodium citrate. Cells were centrifuged again at $2000 \mathrm{rpm}$ for $5 \mathrm{~min}$ and the cell pellet was re-suspended in $250 \mu 150 \mathrm{mM}$ sodium citrate containing $0.1 \mathrm{mg} / \mathrm{ml}$ RNAse A. The cells were incubated for $2 \mathrm{~h}$ at $37^{\circ} \mathrm{C}$. After RNAse-treatment,
$250 \mu 150 \mathrm{mM}$ sodium citrate containing $8 \mu \mathrm{g} / \mathrm{ml}$ PI were added. Cells were separated with a $40 \mu \mathrm{m}$ Cell Strainer (Biologix, Jinan, China), and immediately analyzed with the CytoFLEX S flow cytometer (excitation wavelength $488 \mathrm{~nm}$, bandpass filters with 585/42 nm and 690/50 nm width; Beckman Coulter, Krefeld, 
Germany). At least 20,000 cells per sample were analyzed using FlowJo v9.4.11 (FlowJo, LLC, Ashland, OR, USA).

\section{Image Processing}

If necessary, images were processed using ImageJ 1.46r (National Institutes of Health, USA). Images were auto-adjusted for brightness and contrast.

\section{RESULTS}

\section{Establishment of the Amoebae Plate Test}

In order to find protocols for studying the interaction of amoebae with yeast cells we also tried to establish the commonly used plaque-assay with different media (Figure S1). Although Dictyostelium was able to produce plaques on yeast lawns on different media when spotted on freshly-spread yeast cells, the plaques were not increasing in size, indicating that yeast cells are not the preferred food source for the amoebae. We also investigated the ability of $D$. discoideum to move chemotactically in the direction of yeast cells using an under-agarose chemotaxis assay (Woznica and Knecht, 2006) and discovered that the amoebae were not able to move toward the yeasts (data not shown).

We therefore looked for alternative protocols to investigate the interaction of amoebae with yeast and adapted the amoebae plate test of Albers et al. (2005). Originally, this test was established to investigate the interaction of Acanthamoeba with Legionella bacteria. For our purpose we spread $D$. discoideum cells on HL5-agar, spotted serially dilutions of yeast suspensions on the lawn of amoebae, and observed the growth of the yeast up to $72 \mathrm{~h}$ (Figure 1). It must be mentioned that the amoebae started to produce fruiting bodies between 24 and $48 \mathrm{~h}$ after the spotting of the yeast cells (48-72 $\mathrm{h}$ after spreading of the amoebae). This indicates, again, that the yeast cells were not the preferred food source, leading to starvation and subsequent initiation of the developmental cycle of $D$. discoideum. Additionally, Dictyostelium seemed to not be able to obtain sufficient nutrients from solidified HL5 medium over a longer time period (more than $48 \mathrm{~h}$; the initiation of the social cycle was not observed during the first $24-48 \mathrm{~h}$ after spreading the amoebae). However, we hypothesized that co-incubation of yeasts with amoebae impairs growth of yeasts and tested first several typical laboratory strains (w303a, w303 $\alpha$, w303a/ $\alpha$, Y-187, Y-190, INVSc1, BY4741), "wild type" isolates like Baker's and Brewer's yeast, flocculating strains (BY25558-25561, KV210, KV84; Figure S2), a strain with a cell division defect (TH2-1B), as well as bloodstream isolates (RKI 07-0060, RKI 07-0061, RKI 05-0082-01, RKI 050082-02) in combination with the $D$. discoideum axenic strain AX2 (Figure 2A; Tables 1, 3). As demonstrated in Figure 2A, Baker's and Brewer's yeast grew very well on plates containing amoebae, whereas all (non-flocculating) laboratory strains as well as the flocculating strains were inhibited in growth. Otherwise, strain TH2-1B, which has a cell division defect (Clarke, 2010), and the bloodstream isolates showed intermediate growth on amoebae-containing plates (Figure 2A). The result of the "virulent" S. cerevisiae bloodstream isolates led us to test secondly the interaction of the amoebae with the pathogenic yeasts, C. albicans, C. glabrata, and C. krusei (Figure 2B; Table 4). C. albicans and C. glabrata are the two most common Candidaspecies causing candidemia, whereas C. krusei is rarely found (Guinea, 2014). The two investigated filamentous C. albicans strains SC5314 and ATCC10231 showed very good growth on the amoebae-plates, with slight differences between the highly virulent SC5314 and the less virulent ATCC10231 (Figure 2B; Thewes et al., 2008). C. glabrata is non-filamentous and was comparable in its growth to the S. cerevisiae bloodstream isolates. Interestingly, C. krusei, which can form only pseudohyphae, was found to grow very well on plates with Dictyostelium (Figure 2B).

Subsequently, the ability of other Dictyostelia to interact with yeast cells was tested using species from different taxonomic divisions (Schaap et al., 2006): D. discoideum and D. purpureum from group $4, D$. caveatum from group $3, P$. pallidum from group 2 , and the group $2 /$ group 3 -intermediate species $D$. polycephalum (Figure 2C; Table 2). Except for the D. discoideum strains, all other Dictyostelia were non-axenic and had to be grown in association with bacteria. In the amoebae plate test the yeast strain BY4741 as well as the Baker's yeast grew very well in association with non-axenic Dictyostelia (Figure 2C). Therefore, we decided to work in the following experiments solely with axenic $D$. discoideum strains.

\section{Analysis of Yeast Factors Affecting Growth on Amoebae Plates}

Since huge differences were observed concerning growth in the amoebae plate assay we investigated three different yeast strains in more detail: the Baker's yeast, the bloodstream isolate RKI 070060, and the laboratory strain w303a/ $\alpha$ (compare Figure 2A). To get first insights into the possible mechanisms underlying the differences observed in the amoeba plate test we analyzed the growth of the different strains in various liquid media (YPD, HL5, AXoM; Figure 3). In all three tested media the Baker's yeast showed very robust growth, whereas the laboratory strain w303a/ $\alpha$ always showed the lowest $\mathrm{OD}_{600}$ value. The bloodstream isolate RKI 07-0060 showed intermediate growth between Baker's yeast and w303a/ $\alpha$ (Figures 3A-C).

Using AXoM we next investigated the phagocytosis of the different yeast strains by the amoebae. Here, strain w303a/ $\alpha$ showed the highest uptake rate and the Baker's yeast showed the significantly lowest uptake rate. Again, strain RKI 07-0060 showed an intermediate uptake rate between w303a/ $\alpha$ and Baker's yeast (Figure 3D).

The growth of the yeast during co-incubation with $D$. discoideum was further analyzed in 96-well plates in AXoM by counting colony forming units (cfu) at the indicated time points. Additionally, the survival of $D$. discoideum during co-incubation with yeast cells was monitored using the trypan-blue exclusion assay. Here, the cells were incubated in SP-buffer to check if the amoebae could potentially use the yeast cells as nutrients. As can be seen in Figure 4A, no significant difference could be observed in the survival of $D$. discoideum with or without yeast cells. This result was also independent of the S. cerevisiae strain used (data not shown). On the contrary, growth of the yeast strains during co-incubation 
A

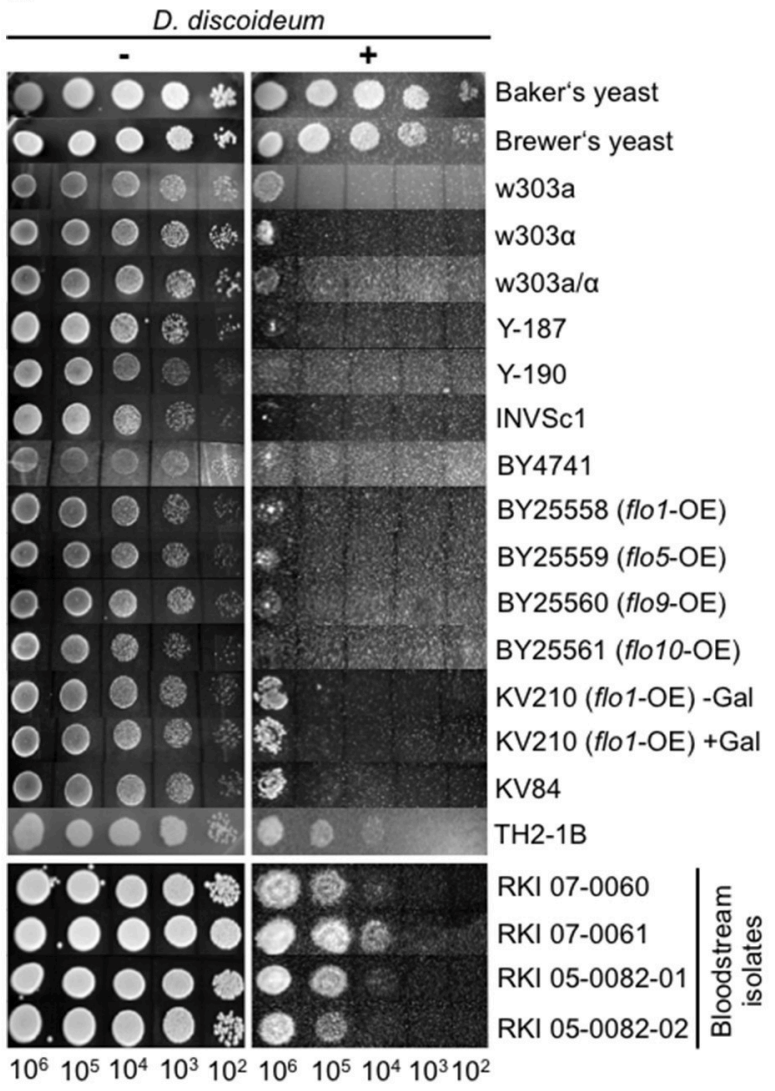

B

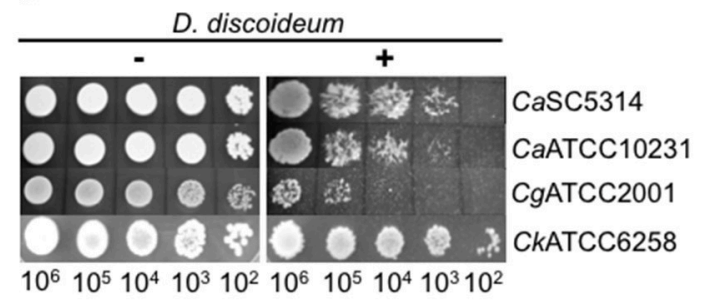

C

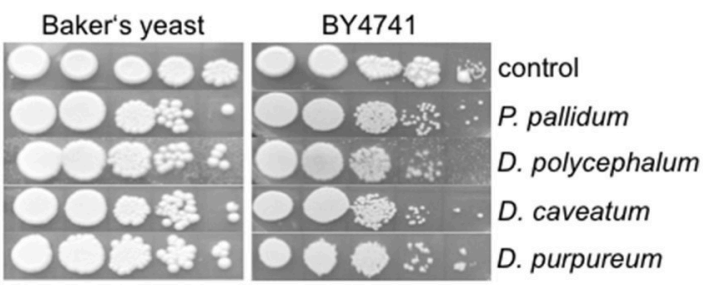

$10^{6} 10^{5} 10^{4} 10^{3} 10^{2} 10^{6} 10^{5} 10^{4} 10^{3} 10^{2}$
CaATCC10231

CgATCC2001 


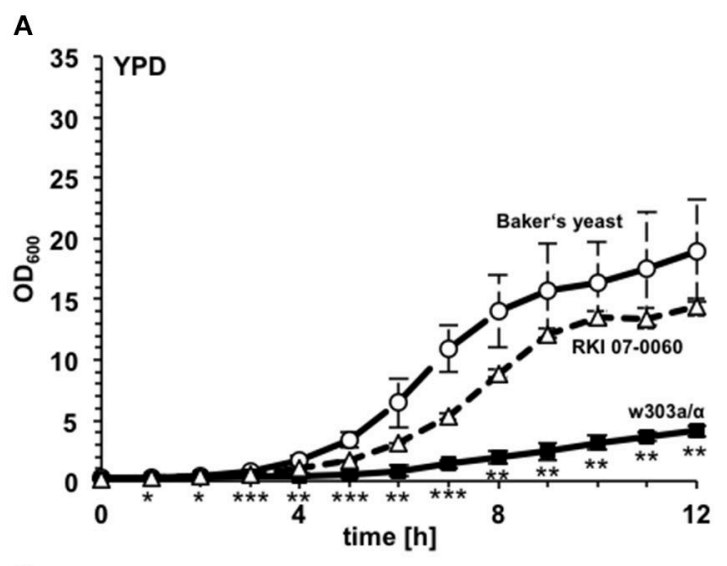

C

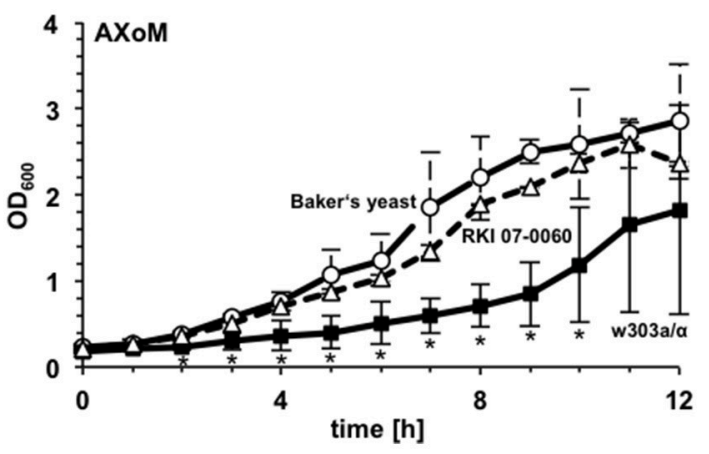

B

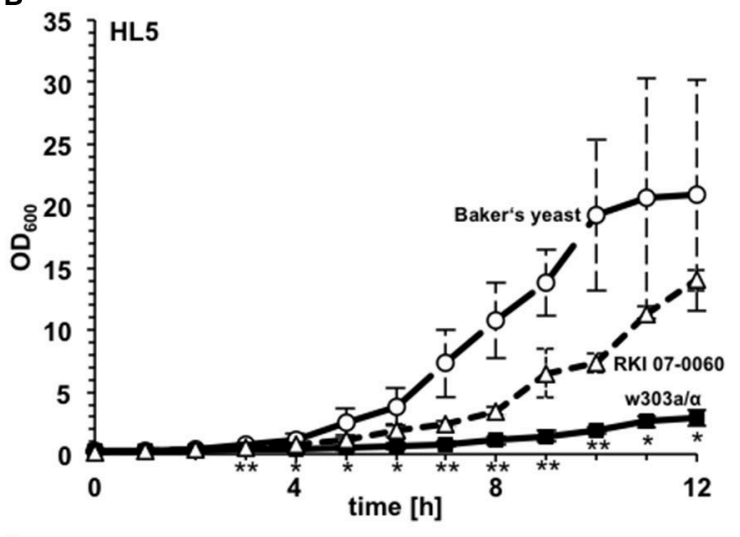

D

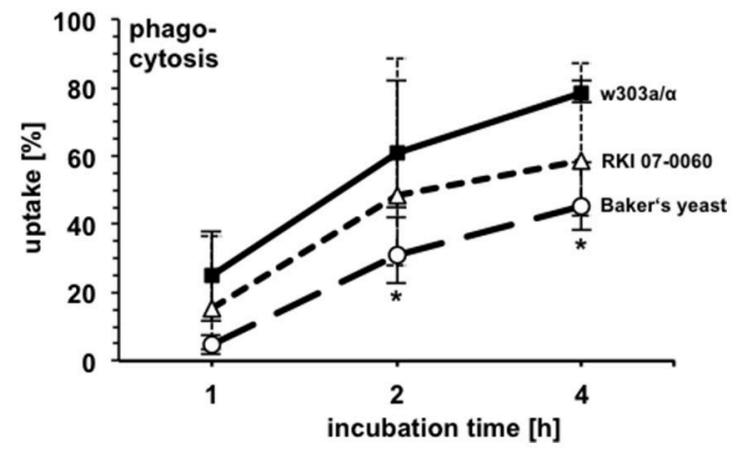

FIGURE 3 | Growth characteristics and phagocytosis rate of different S. cerevisiae strains. Growth of the Baker's yeast, the laboratory strain w303a/ $\alpha$, and the patient isolate RKI 07-0060 was monitored in YPD (A), HL5 (B), and AXoM (C). *significant difference between Baker's yeast and w303a/ $\alpha$ with $P$ < 0.05;

**significant difference between Baker's yeast and w303a/ $\alpha$, and between RKI 07-0060 and w303a/ $\alpha$, resp., with $P<0.05$; ***significant difference between Baker's yeast and w303a/ $\alpha$, between RKI 07-0060 and w303a/ $\alpha$, and between Baker's yeast and RKI 07-0060, resp., with $P<0.05$. (D) Phagocytosis rate of different S. cerevisiae strains during co-incubation with $D$. discoideum AX2. *significant difference between Baker's yeast and w303a/ $\alpha$ with $P<0.05$. Differences between RKI 07-0060 and Baker's yeast were non-significant. All data are represented as mean \pm standard deviation.

Lelong et al., 2011), genes involved in the general stress response (CNA-RNAi, CNB-RNAi) (Boeckeler et al., 2006; Thewes et al., 2014), and genes involved in autophagy or phagosome maturation $\left(\operatorname{atg} 1^{-}, \operatorname{atg} 5^{-}, \operatorname{atg} 6^{-}, \operatorname{atg} 7^{-}, \operatorname{atg} 8^{-}\right.$, dymA ${ }^{-}$) (Wienke et al., 1999; Otto et al., 2003, 2004; Gopaldass et al., 2012). Additionally, we tested a mutant strain, which showed a precocious developmental cycle $\left(r d e A^{-}\right)$(Chang et al., 1998).

As demonstrated in Figure 5A, mutations in most of the genes had no significant effect on the predation potential of $D$. discoideum toward yeast cells. However, some gene mutations resulted in slight to moderate impairment of the amoebal predation potential in a yeast-strain-dependent manner. For instance, the calcineurin RNAi mutants CNA-RNAi and CNBRNAi, respectively, showed slight reduction in growth of the laboratory strain w303a, whereas the other two yeast strains were not affected in their growth. Similar results could be observed for $\mathrm{kill}^{-}$and $\mathrm{rdeA}^{-}$. For the kil2 ${ }^{-}$mutant growth of w303a and Baker's yeast was reduced. The most prominent mutations affecting growth of the different yeast strains were involved in autophagy of $D$. discoideum. Here, two types of effects could be observed: the atg $1^{-}$mutant impaired growth of all three yeast strains, whereas the $\operatorname{atg} 6^{-}$mutant promoted an increase of growth of all yeast strains. The weaker growth of the yeast during co-incubation with the $\operatorname{atg} 1^{-}$mutant seemed to be in contrast to earlier publications using pathogenic bacteria (Jia et al., 2009; Lampe et al., 2016). Therefore, we asked if the atg1 ${ }^{-}$mutant had defects in phagocytosis of yeast cells, if the growth inhibition rate is really higher than in the wild type, or if the mutant could also abolish the growth of pathogenic yeast. Concerning the uptake, Figure 5B shows that phagocytosis of $w 303 \mathrm{a} / \alpha$ was significantly reduced after 2 and $4 \mathrm{~h}$ in the $\operatorname{atg} 1^{-}$mutant compared to the parental strain DH1. The yeast survival rate in co-incubation with $\operatorname{atg}^{-}$cells was lower than in wild type D. discoideum cells (Figure 5C) and $\operatorname{atg} 1^{-}$affected also growth of C. albicans and C. glabrata (Figure 5D).

Taken together, host factors involved in the intracellular killing of bacteria such as Kil1 and Kil2 are also relevant for the interaction with yeast cells, whereas factors involved in phagoand exocytosis or the general stress response are only slightly involved. Impairment of autophagy of the host plays a prominent role for the interaction with different effects: complete loss of autophagosome formation $\left(\operatorname{atg} 1^{-}\right)$results in decreased growth 
A

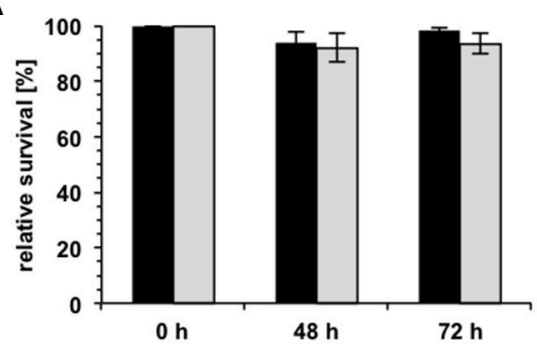

-Dd - ScBY4741 aDd + ScBY4741

C

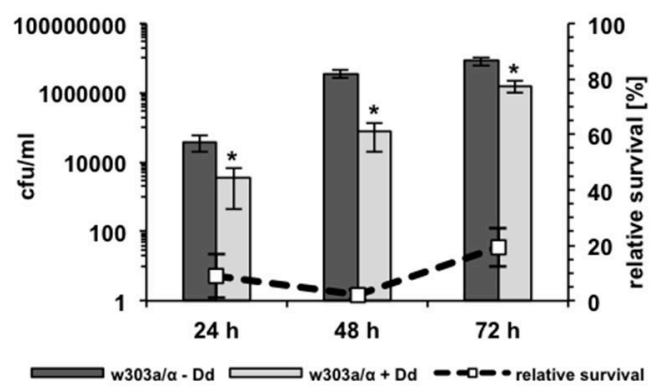

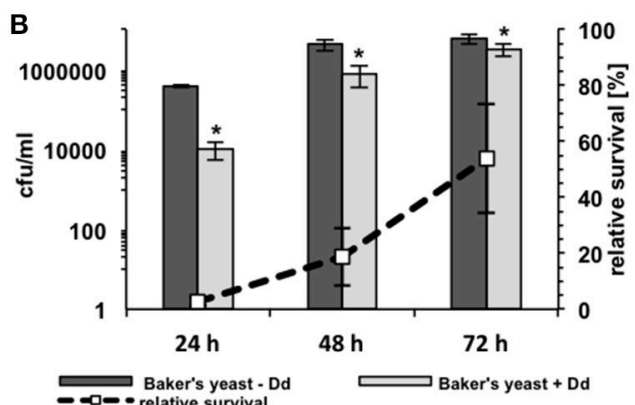

D

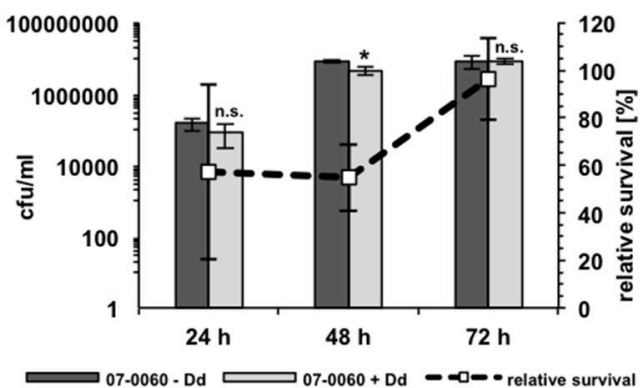

FIGURE 4 | Survival of $\boldsymbol{D}$. discoideum and S. cerevisiae during co-incubation. (A) Survival of D. discoideum AX2 (Dd) in SP-buffer with (gray bars) or without (black bars) S. cerevisiae BY4741 as revealed by trypan blue staining. No significant differences could be detected. (B) Survival of Baker's yeast with (light-gray bars) or without (dark-gray bars) D. discoideum AX2 in AXoM as measured by counting colony-forming units (cfu). (C) Survival of the laboratory S. cerevisiae strain w303a/ $\alpha$ with (light-gray bars) or without (dark-gray bars) D. discoideum AX2 in AXoM as measured by counting cfu. (D) Survival of the S. cerevisiae bloodstream isolate RKI 07-0060 with (light-gray bars) or without (dark-gray bars) D. discoideum AX2 in AXoM as measured by counting cfu. The dashed lines in (C,D) represent the percentage survival rate of the yeast strain during co-incubation with $D$. discoideum as compared to the survival rate without amoebae (=100\%). All data are represented as mean \pm standard deviation. ${ }^{*}$ significant reduction of cfu/ml compared to yeast cells without amoebae with $P<0.05$. n.s., no significant difference.

of yeast cells whereas mutations in other autophagy genes (e.g., atg6 ${ }^{-}$) results in increased growth of yeast cells.

\section{Fungal Virulence Factors Determine Interaction of $D$. discoideum with C. albicans}

Besides the investigation of the interaction of $D$. dicoideum with different non-pathogenic yeast strains we tested whether the amoebae could be used as a tool for identifying putative virulence factors of pathogenic yeast. Therefore, we investigated the role of known C. albicans virulence factors in the amoebae plate test. At first, we chose mutant strains with defects in hyphae formation ( $\Delta c p h 1, \Delta d f g 16, \Delta e f g 1, \Delta h g c 1, \Delta c p h 1 / \Delta e f g 1$ ) (Liu et al., 1994; Lo et al., 1997; Zheng et al., 2004; Thewes et al., 2007), mutants with defects in the expression of secreted aspartic proteases ( $\Delta$ sap1-3, $\Delta$ sap4-6) (Sanglard et al., 1997; Kretschmar et al., 2002), as well as a mutant with defects in the glyoxylate cycle ( $\Delta$ icl1) (Ramírez and Lorenz, 2007). Figure 6A reveals that the non-filamentous $\Delta c p h 1 / \Delta e f g 1$ double mutant, the nonfilamentous $\Delta h g c 1$ mutant, and the glyoxylate cycle mutant $\Delta i c l 1$ had reduced resistance toward predation by the amoebae. The $\Delta e f g 1$ mutant was only slightly affected and the $\Delta c p h 1$ and $\Delta d f g 16$ mutants were not affected. The secreted aspartic protease mutants $\Delta$ sap1-3 and $\Delta$ sap4-6 also showed a growth reduction in association with amoebae compared to the control strains. However, these mutant strains also displayed a growth reduction on the AXoM plates without amoebae (Figure 6A, left panel). We confirmed that the mutants with defects in hyphae formation also formed no hyphae in contact with $D$. discoideum (Figure S3A).

Recently, stable haploid C. albicans strains have been described (Hickman et al., 2013). We wondered if the amoebae plate test could be used with those strains. Therefore, the resistance of the haploid C. albicans strains GZY805 and GZY822 toward predation by $D$. dicoideum was compared, and we found that both strains were slightly more susceptible compared to the "parental" diploid strain SC5314 (Figure 6B). Furthermore, we tested the available haploid mutant strains, which also have defects in hyphae formation. For the haploid $\Delta h g c 1$ strain (GZY806), as well as for the haploid mutant strains $\Delta s e c 3$ (GZY833) and $\Delta r v s 167$ (GZY834), we found a reduction in the resistance toward predation compared to the parental control strains GZY805 and GZY822, respectively (Figure 6B). For the haploid mutant $\triangle$ sla1 (GZY824) no difference was seen compared to the control strain and $\triangle a c e 2$ (GZY825) showed a slight increase in the resistance toward predation. Investigating the ability of the haploid mutants to produce hyphae in contact with $D$. discoideum revealed that besides the haploid $\Delta h g c 1$, all other mutants still produced at least pseudohyphae (Figure S3B). Furthermore, the haploid status of the cells was confirmed by propidium iodide staining and subsequent flow cytometry (Figure S4).

Taken together, these results show that known virulence factors of C. albicans such as hyphae formation and a functional 
A

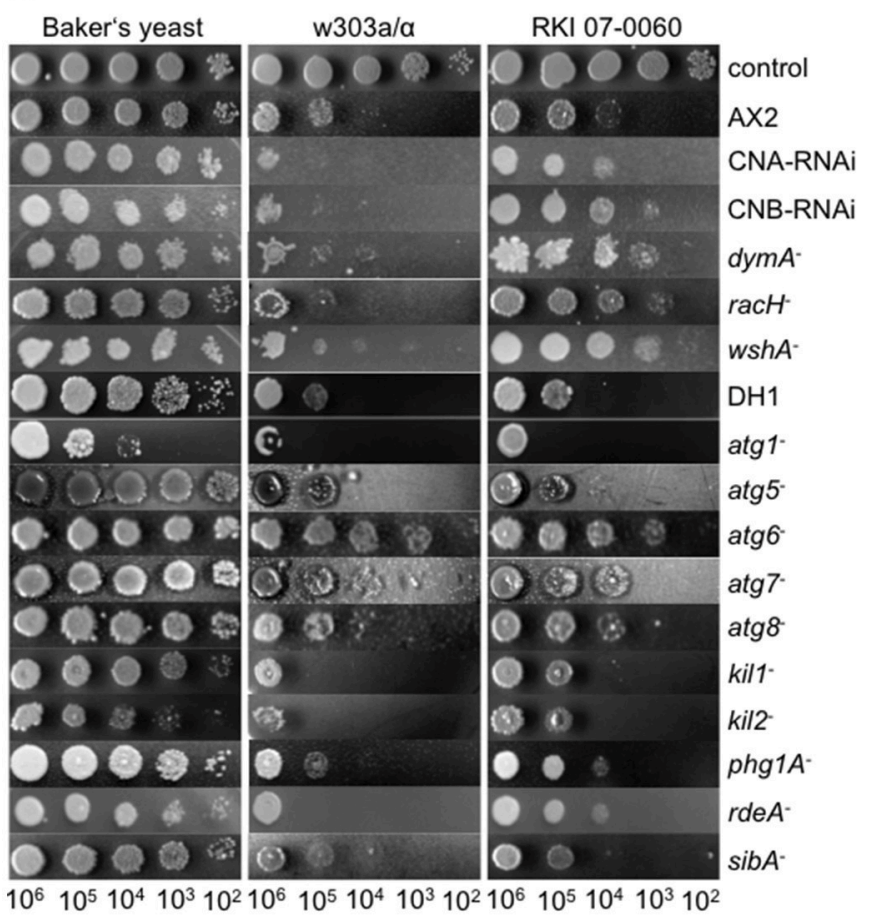

B

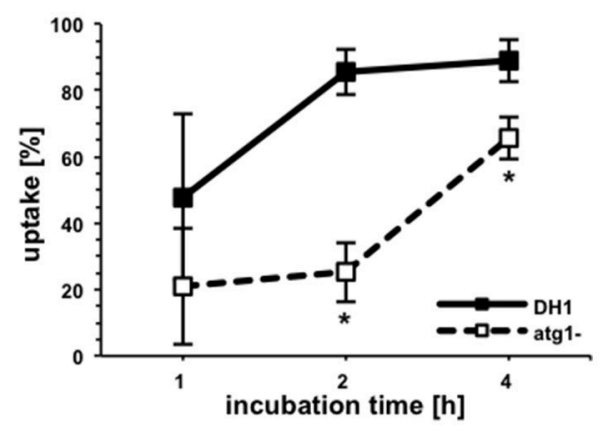

C

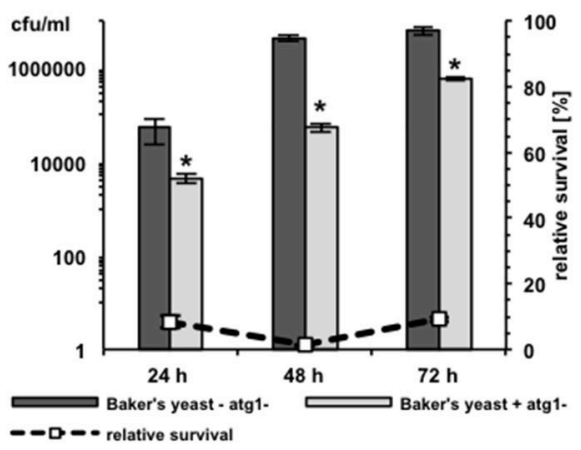

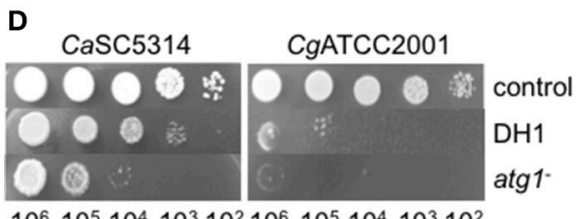

$10^{6} 10^{5} 10^{4} 10^{3} 10^{2} 10^{6} 10^{5} 10^{4} 10^{3} 10^{2}$

FIGURE 5 | Different host factors are involved in the interaction of $\boldsymbol{D}$. discodieum with yeast cells. (A) Amoebae plate test of the three $S$. cerevisiae strains Baker's yeast, w303a/ $\alpha$, and RKI 07-0060 in combination with different $D$. discodieum mutant cell lines and their parental strains AX2 and DH1. As a control, yeast cells were spotted on HL5-agar without amoebae. (B) Phagocytosis-rate of S. cerevisiae w303a/ $\alpha$ with D. discoideum atg1- mutant (dashed line) and its parental strain $\mathrm{DH} 1$ (solid line). Data are represented as mean \pm standard deviation. *significant difference between atg1- and $\mathrm{DH} 1$ with $P<0.05$. (C) Survival rate of Baker's yeast during co-incubation with (light-gray bars) or without (dark-gray bars) atg $1^{-}$. The dashed line represents the percentage survival rate of the yeast strain during co-incubation with $D$. discoideum as compared to the survival rate without amoebae $(=100 \%)$. Data are represented as mean \pm standard deviation. *significant reduction of cfu/ml compared to yeast cells without $\operatorname{atg} 1^{-}$with $P<0.05$. (D) Amoebae plate test of $D$. discoideum atg $1^{-}$and its parental strain $\mathrm{DH} 1$ with pathogenic C. albicans and C. glabrata strains.

glyoxylate cycle also play a role during the interaction with amoebae.

\section{C. albicans Forms Hyphae in Association with $D$. discoideum in a Contact-Independent Manner}

Although the temperature $\left(22^{\circ} \mathrm{C}\right)$ is quite low and the media used did not contain any hyphae-inducing substances we observed in our assays that C. albicans SC5314 (and other strains as well) formed hyphae after phagocytosis or contact with $D$. discoideum (Figure 7A). To test if direct cell-cell contact between yeast and amoebae was necessary, both species were incubated in 24-well plates using Transwell ${ }^{\circledR}$ inserts, which resulted in separation of $C$. albicans from $D$. discoideum by a porous membrane
(Figure 7B). As can be seen in Figure 7C direct cell-cell contact was not necessary for the hyphae production of $C$. albicans. Furthermore, lysed $D$. discoideum cells also induced hyphae formation of C. albicans (Figure 7C).

To get first insights in the putative nature of the hyphaeinducing compound of $D$. discoideum we treated cell lysates in different ways, such as incubation at different temperatures $\left(-20,4,95^{\circ} \mathrm{C}\right)$ or differential centrifugation $(500 \mathrm{~g}, 5000 \mathrm{~g})$. Figure 7D shows that treatment of the $D$. discoideum lysates with very low $\left(-20^{\circ} \mathrm{C}\right)$ or very high $\left(95^{\circ} \mathrm{C}\right)$ temperatures completely abolished hyphae formation of $C$. albicans. This effect was also observed after centrifugation of the lysate at $5000 \mathrm{~g}$. Incubation of the cell lysate at moderately low temperature $\left(4^{\circ} \mathrm{C}\right)$ and moderate centrifugation $(500 \mathrm{~g}$ ) led to a partial reduction of hyphae formation (Figure 7D). Since D. discoideum secretes 
A

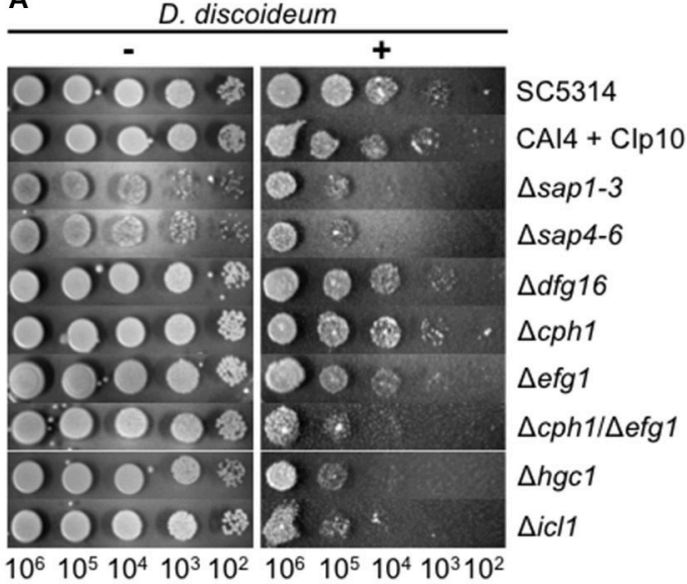

B

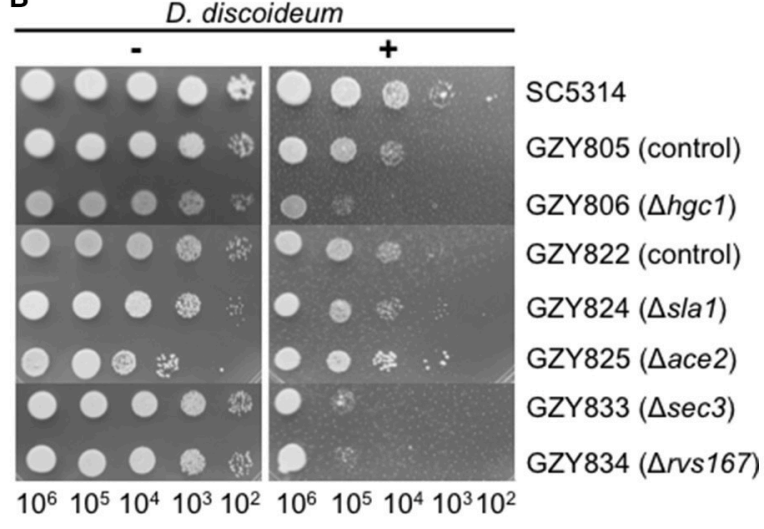

FIGURE 6 | Known virulence factors of C. albicans are involved in the interaction with D. discoideum AX2. (A) Amoebae plate tests of different diploid C. albicans mutant strains and their parental strains SC5314 and CAI4 + Clp10, respectively. (B) Amoebae plate tests of different haploid C. albicans mutant strains and their parental strains GZY805 and GZY822, respectively.

cyclic adenosine-3,'5'-monophosphate (cAMP) upon starvation (Du et al., 2015), and the cAMP-protein kinase pathway is a central pathway for hyphal initiation in C. albicans (Lu et al., 2014), we thought that secreted cAMP might trigger the hyphae formation of $C$. albicans. Therefore, we added different concentrations (10-100 nM) of cAMP to C. albicans in AXoM but found no hyphae formation (Figure S5).

Although the temperature at $22^{\circ} \mathrm{C}$ is quite low for hyphae production of $C$. albicans, $D$. discoideum secretes a yet unidentified diffusible factor that can trigger hyphae formation.

\section{DISCUSSION}

It has been proven in the last 15 years that the social amoeba $D$. discoideum can be used as a suitable host model to study interaction with pathogenic bacteria. However, research dealing with the interaction of $D$. discoideum with pathogenic fungi is still limited. Only a few studies using Cryptococcus neoformans or Aspergillus fumigatus have been conducted so far (Steenbergen et al., 2003; Chrisman et al., 2011; Hillmann et al., 2015; Mattern et al., 2015). On the other hand, yeast cells have been used for a long time to study phagocytosis of $D$. discoideum (Rivero and Maniak, 2006) but the impact of different yeast strains, or the fate of the yeast cells was usually not investigated. We present for the first time a comprehensive study of the interaction of $D$. discoideum with apathogenic and pathogenic yeast; a convenient method for co-cultivation to investigate fungal strains is introduced as well.

\section{Yeast Factors Playing a Role for the Interaction with $D$. discoideum}

After having successfully adapted the amoebae plate test originally developed by Albers et al. (2005), we observed that different S. cerevisiae strains showed differential susceptibility toward predation by the amoebae. As plaque assays used to study the interaction of $D$. discoideum with bacteria (Froquet et al., 2009) failed to study the interaction with yeast, our first intention was that the size of the yeast particles or flocs of yeast cells might have an impact. However, testing several flocculating yeast strains overexpressing different flo-genes (Smukalla et al., 2008; Beauvais et al., 2009; Nonklang et al., 2009), no correlation was observed between flocculation and resistance toward predation. Flocculation of yeast cells is a reversible, calcium-dependent process (Verstrepen et al., 2003) and it is likely that D. discoideum can release attached cells out of flocs. For $S$. cerevisiae strain TH2-1B, which has a budding defect, it has been shown that $D$. discoideum is able to divide incompletely-budded yeast particles, allowing them to engulf the first encountered portion (Clarke, 2010). TH2-1B has deletions in the genes MNN1 and MNN2, both encoding mannosyltransferases, and the mutant strain is altered in the structure of the cell wall mannoprotein, resulting in the budding defect (Clarke, 2010). Nevertheless, as TH2-1B was partially resistant toward predation in our assay, particle size might contribute at least partially to the observed resistance. The role of the particle size is further supported by the results obtained with non-axenic amoebal species. None of the nonaxenic species was able to reduce the growth of the yeast cells. Recently it has been shown that only axenic $D$. discoideum strains are able to phagocytize bigger particles such as yeast cells, due to a mutation in $a x e B$, a gene encoding neurofibromin that limits the size of macropinosomes (Bloomfield et al., 2015). This might be the reason why non-axenic strains were not able to phagocytize yeast cells. But it is not only the particle size that has an impact on the predation of yeast cells by $D$. discoideum. Other factors must play a role, since the "natural" Baker's and Brewer's yeast-as well as the bloodstream isolates-were resistant toward predation without having a bigger particle size compared to predationsusceptible laboratory strains. Different virulence-related traits have been described in S. cerevisiae, including growth at elevated 


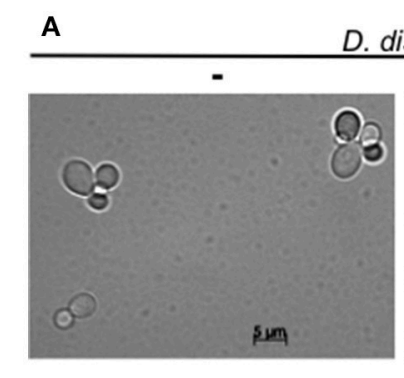

C
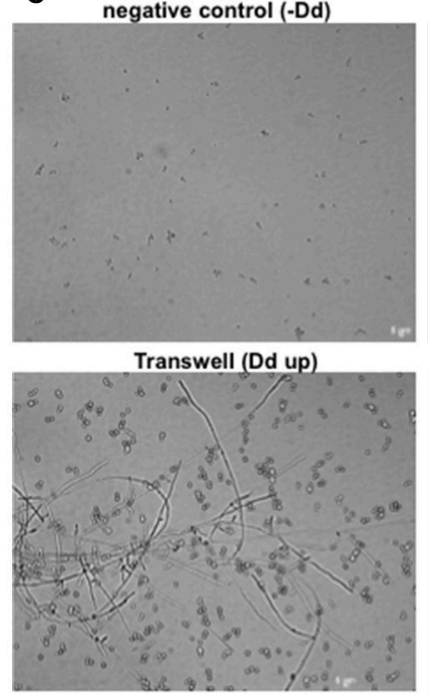

Transwell (Dd-lysate up)

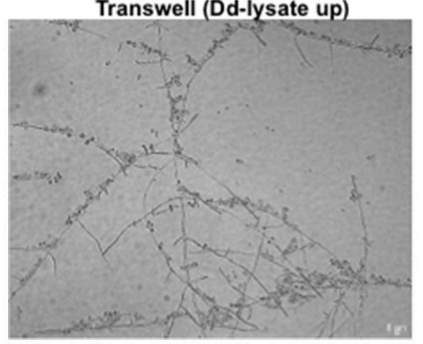

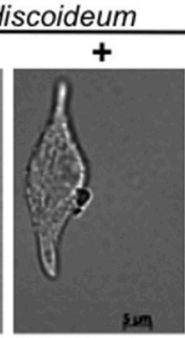

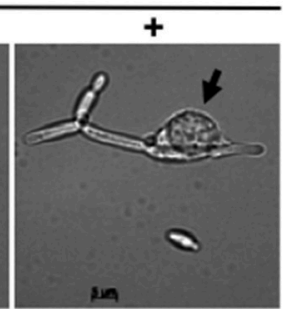

positive control (+Dd/cell-cell-contact)

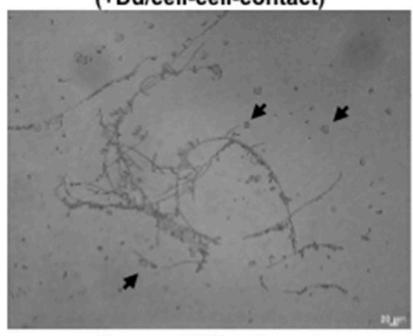

Transwell (Dd+Ca up)

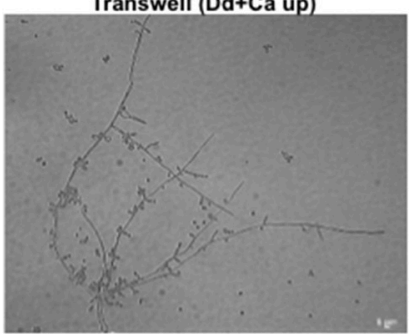

Triton $\mathrm{X}-100$ control

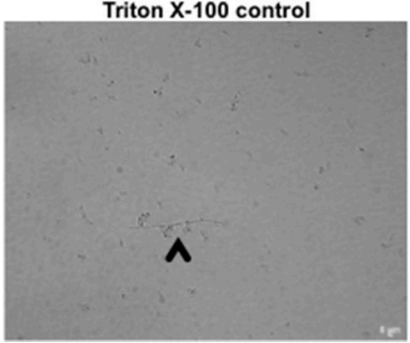

B

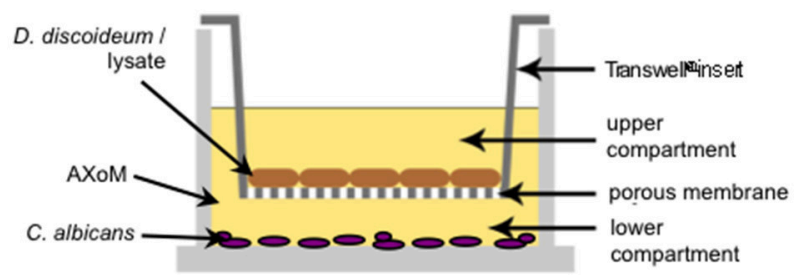

D

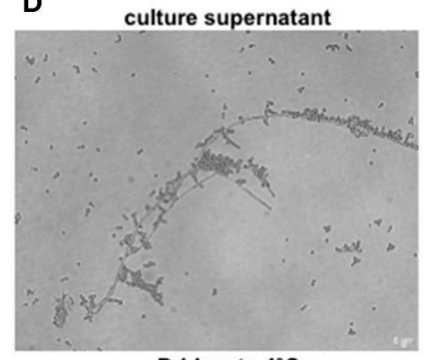

Dd-lysate $4^{\circ} \mathrm{C}$

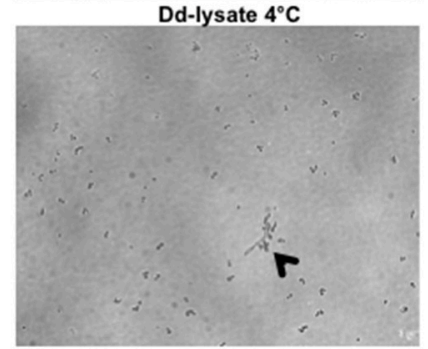

Dd-lysate $500 \mathrm{~g}$

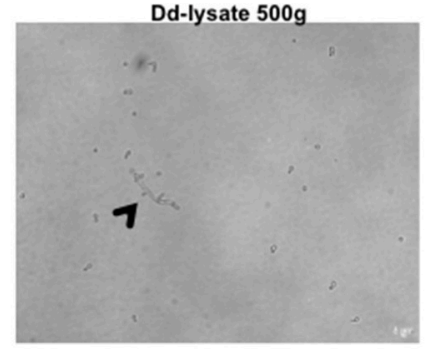

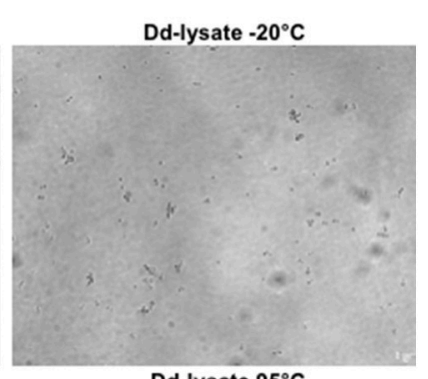

Dd-lysate $95^{\circ} \mathrm{C}$

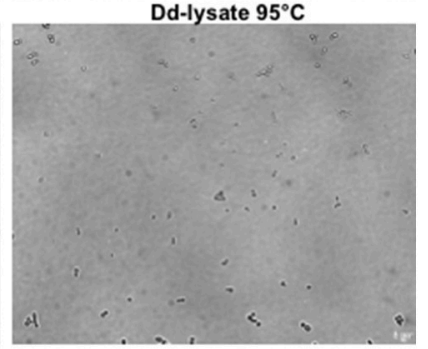

Dd-lysate $5,000 \mathrm{~g}$

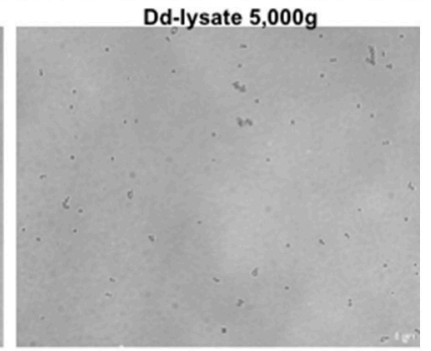

FIGURE 7 | Hyphae formation of C. albicans during co-incubation with $\boldsymbol{D}$. discoideum is contact-independent. (A) C. albicans SC5314 produces hyphae inside (middle panel) and outside (right panel) D. discoideum AX2. Without amoebae no hyphae formation could be detected (left panel). The arrow indicates D. discoideum in direct contact with C. albicans filaments. (B) Scheme of the Transwell ${ }^{\circledR}$-assay. Cells were separated in AXoM by a porous membrane (pore size 0.04 $\mu \mathrm{m})$. The upper compartment contained D. discoideum AX2 cells or cell lysate. The lower compartment always contained C. albicans SC5314. (C) Results of the Transwell ${ }^{\circledR}$-assay. As a negative control C. albicans cells were incubated in AXoM without D. discoideum, as positive control C. albicans was incubated in AXoM with D. discoideum AX2 but without Transwell ${ }^{\circledR}$-insert (cell-cell contact; arrows). Arrowheads indicate pseudohyphae formation of $C$. albicans. (D) Hyphae formation of C. albicans with differentially treated $D$. discoideum AX2 cell-lysates. Only untreated culture supernatant was able to induce hyphae formation. Arrowheads indicate pseudohyphae formation.

temperatures and the ability to form pseudohyphae (McCusker et al., 1994), phenotypic switching (Clemons et al., 1996), or resistance to oxidative stress (Diezmann and Dietrich, 2009). We tested several phenotypic traits of the different yeast strains including growth at $42^{\circ} \mathrm{C}$, resistance toward $\mathrm{H}_{2} \mathrm{O}_{2}$, or resistance toward cell surface perturbing agents such as SDS or congo red; we found no big differences between the tested strains that could have been correlated to the resistance against predation of the yeast by amoebae (data not shown). However, Baker's yeast and the bloodstream isolate RKI 07-0060 showed better growth in liquid culture as well as reduced phagocytosis rates compared to strain w303a/ $\alpha$. Therefore, general growth characteristics and the ability to prevent phagocytosis correlate to the resistance toward predation on our amoeba plate test. Time-lapse microscopy revealed that yeast strains might have evolved different strategies to face predation by amoebae. Whereas laboratory strains have probably lost the ability to resist predation, bloodstream isolates were obviously not efficiently recognized by $D$. discoideum, leading to reduced uptake. Further, flocculation of yeast cells, as can be seen for the Baker's yeast, was an effective strategy 
to avoid predation. However, flocculation as a tool to prevent phagocytosis seems to work only in submerged cultures in contact with amoebae. During co-incubation on solid substrates, as in the amoebae plate test, flocculation of yeast cells had only a minor impact and the Baker's yeast showed no increased flocculation when grown in YPD. The molecular basis for these differences will need to be determined in future studies, yet slight differences in cell wall composition of the different strains might be a reason for the observed differences concerning phagocytosis. For macrophages, several studies have shown that different cell wall components, especially mannan, are needed for the recognition of yeast cells by the phagocyte (Keppler-Ross et al., 2010; McKenzie et al., 2010; Lewis et al., 2012). However, further details of the interaction between yeast and macrophages are only poorly understood (Kong and Jabra-Rizk, 2015). In the future, D. discoideum might be a suitable host model to elucidate further details of yeast-phagocyte interaction. Additionally, the amoeba plate test-in combination with other methods to determine virulence-related traits-might be useful for risk assessment of S. cerevisiae strains.

\section{Growth of Yeast Cells is Affected by Different Host Factors}

Since-in contrast to many other host models-D. discoideum is highly amenable to genetic manipulations, amoebal factors, which might be involved in the interaction with yeast cells, were investigated. At first, we concentrated on factors that have been described as playing a role in the interaction with bacteria. Whereas genes involved in phago-/exocytosis or phagosome maturation $\left(\mathrm{racH}^{-}, w s h A^{-}, \mathrm{phg} 1 A^{-}, \mathrm{sib} A^{-}, \mathrm{dym} A^{-}\right.$) (Wienke et al., 1999; Cornillon et al., 2000, 2006; Somesh et al., 2006; Carnell et al., 2011) and genes involved in the general stress response (CNA-RNAi, CNB-RNAi) (Boeckeler et al., 2006; Thewes et al., 2014) were only slightly involved in the interaction with yeast cells, genes involved in intracellular killing of bacteria $\left(k_{i l 1^{-}}\right.$, kil2 $^{-}$) (Benghezal et al., 2006; Lelong et al., 2011) and genes involved in autophagy $\left(\operatorname{atg} 1^{-}, \operatorname{atg} 5^{-}, \operatorname{atg} 6^{-}, \operatorname{atg} 7^{-}, \operatorname{atg} 8^{-}\right)$ (Otto et al., 2003, 2004; Gopaldass et al., 2012) had a larger impact during the interaction with different $S$. cerevisiae strains. The gene kil1 encodes the only characterized sulfotransferase in Dictyostelium and mutation of this gene led to defects in intracellular killing of bacteria probably via a still unidentified sulphated factor (Le Coadic et al., 2013). This effect seems to be bacteria-specific, since increased predation of yeast cells by the kil1 $^{-}$mutant was observed during the interaction with yeast. Similar results were obtained with the mutant $k i l 2^{-}$. Kil2 is a putative magnesium pump involved in maintaining the phagosomal magnesium concentration optimal for proteolysis and efficient killing of Klebsiella pneumoniae (Lelong et al., 2011). Killing of other bacteria was not affected by the mutation of kil2. In our assay, similar to $\mathrm{kil1}^{-}$, the $\mathrm{kil2}^{-}$strain showed increased predation of yeast cells. Both genes, kil1 and kil2, therefore seem to have species-specific roles during intracellular killing of the prey. However, the underlying mechanisms are not fully understood: neither for bacteria nor for yeasts, and must be elucidated in future studies.
Concerning the autophagy mutants two opposite and counterintuitive phenotypes could be detected in the amoebae plate test: $\operatorname{atg} 1^{-}$cells showed higher predation of yeast cells, whereas $\operatorname{atg} 6^{-}$cells showed lower predation of yeast cells. It is known that mutations in different autophagy-related genes led to differences in the phenotypical outcome with $\operatorname{atg} 1^{-}$ always showing the most severe defects compared to other atgmutants (Otto et al., 2004). Atg1 is required for the initiation of the autophagosome formation. Loss of atg1 completely blocks autophagosome formation, whereas loss of other components of the autophagic machinery can still result in production of very small autophagosomes (Abeliovich et al., 2000). However, we would have suspected that impairment of autophagy results in an increased growth of yeast cells, since autophagy has been connected to cellular immunity (Deretic et al., 2013; Winchell et al., 2016). This seems to be partially true for $D$. discoideum atg $6^{-}$but for the atg1 ${ }^{-}$mutant the opposite effect was observed, which is in contrast to studies using pathogenic bacteria (Jia et al., 2009; Lampe et al., 2016). The reason for this discrepancy is currently not known, but since the atg $1^{-}$ mutant is not able to produce autophagosomes at all, the cells are unable to recycle cellular components to gain nutrients and the cells might therefore be "hungrier," allowing efficient degradation of yeast cells. Another possible explanation would be that yeast cells use the autophagic machinery to escape from phagocytes, as has been shown for mycobacteria (Gerstenmaier et al., 2015). Non-lytic expulsion from macrophages has also been observed for yeast cells (Ma et al., 2006; Bain et al., 2012). It might be possible that yeast cells are "locked" in atg $1^{-}$mutants, giving the amoeba the ability to efficiently kill the yeasts. Yeast cell uptake seems to have a minor impact in the $\operatorname{atg} 1^{-}$mutant, as the reduced phagocytosis rate does not correlate with the increased growth inhibition. Future studies will have to dissect the exact role of Atg1 for phagocytosis, intracellular killing, and non-lytic expulsion of yeast cells in $D$. discoideum.

In general, the impact of autophagy for the interaction with fungi is controversially discussed and depends on the investigated fungus, the host, and the atg-gene (Lenz et al., 2011; Qin et al., 2011; Nicola et al., 2012; Rosentul et al., 2014; Smeekens et al., 2014; Kanayama et al., 2015; Akoumianaki et al., 2016). Investigating different atg-mutants in the same host with different fungal species, our study shows that the impact of autophagy seems to be related to the mutated atg-gene. This again reflects the power of $D$. discoideum as a suitable host model to investigate the interaction with different yeast species.

At this point, it should be mentioned that atg $1^{-}$mutants cannot develop properly and arrest in their developmental cycle as loose mounds (Otto et al., 2004). This phenotype might have an impact in our amoebae plate test (longer persistence as single amoebae $=$ higher predation rate). However, the $p h g 1 A^{-}$mutant has a similar developmental defect compared to the $\operatorname{atg} 1^{-}$mutant (Benghezal et al., 2003) and showed no increased predation of yeast cells in our assay. Additionally, we tested a "rapid development" mutant $\left(r d e A^{-}\right)$(Chang et al., 1998) and found a rather increased predation than decreased predation of yeast cells. These results indicate that the persistence as amoebal cell 
per se only had minor impact on the interaction with yeast cells in the amoebae plate test.

\section{Known Virulence Factors of C. albicans Are Required for the Interaction with D. discoideum}

In order to validate the power of $D$. discoideum as a host model system for pathogenic yeast we investigated the role of known C. albicans virulence factors during co-incubation with the amoebae. Mutant strains with defects in hyphae formation $(\Delta c p h 1, \Delta d f g 16, \Delta e f g 1)$ had no or only little effect on the interaction with $D$. discoideum, although all three mutants formed no hyphae $(\Delta d f g 16)$ or merely short pseudohyphae $(\Delta c p h 1, \Delta e f g 1)$ in contact with amoebae. Only the $\Delta h g c 1$ mutant and the $\Delta c p h 1 / \Delta e f g 1$ double mutant, both locked in the yeast form (Lo et al., 1997; Zheng et al., 2004), showed reduced resistance toward predation by the amoebae. This correlates with earlier results showing that, beside morphogenesis defects, the $\Delta h g c 1$ and $\Delta c p h 1 / \Delta e f g 1$ mutants also have a markedly reduced virulence $(\Delta h g c 1)$ (Zheng et al., 2004) or are completely avirulent $(\Delta c p h 1 / \Delta e f g 1)$ (Lo et al., 1997) in a mouse model. The observed phenotypes of the $\Delta c p h 1$ and $\Delta e f g 1$ single mutants also are in accordance with a previous study investigating the interaction of C. albicans with human blood (Fradin et al., 2005). This study revealed that the $\Delta c p h 1$ mutant was not more susceptible toward predation by monocytes than the wild type. Further, the $\Delta$ efg1 mutant showed a slight decrease in its survival rate during incubation with monocytes, which is comparable to the slightly reduced growth of the mutant in the amoebae plate test. The putative $\mathrm{pH}$-sensor Dfg16 is involved in the correct $\mathrm{pH}$ sensing under alkaline conditions (Barwell et al., 2005; Thewes et al., 2007). Although the $\Delta d f g 16$ mutant showed no increased susceptibility toward predation by amoebae, it was not able to form hyphae during co-incubation with $D$. discoideum. The $\mathrm{pH}$ value of the AXoM medium used is around 6.7, indicating that the $\mathrm{pH}$ alone is not responsible for the filamentation defect of $\Delta d f g 16$. Similar results were obtained using the cell culture medium M199 adjusted to different $\mathrm{pH}$ values. Here, the wild type produced hyphae in the range of $\mathrm{pH} 5-8$, whereas $\Delta d f g 16$ produced no hyphae at all at $\mathrm{pH} 8$ and had strong filamentation defects at pH 7 and below (Thewes et al., 2007 and unpublished results). The results of the interaction of $D$. discoideum with different mutants defective in hyphae formation imply thatbeside morphogenesis-other factors regulated via Hgcl, Cph1, and/or Efg1 are crucial for the survival of C. albicans during coincubation with amoebae. The significance of hyphae formation for the resistance toward predation is underlined by the observed hyphae formation of $C$. albicans even without direct contact to D. discoideum. This is in contrast to C. neoformans, where direct cell-cell contact between fungus and amoebae was necessary for capsular enlargement (Chrisman et al., 2011). These results led to the assumption that $D$. discoideum secretes a factor which triggers hyphae formation in C. albicans. This factor is not cAMP, which is secreted by starving $D$. discoideum cells (Du et al., 2015) and important for hyphal initiation in C. albicans (Lu et al., 2014). The nature of this heat- and cold-sensitive factor has to be determined in future studies.
Another protein involved in the interaction between D. discoideum and C. albicans is the isocitrate lyase Icll, representing one of the key components of the glyoxylate cycle. For S. cerevisiae and C. albicans it has been shown that the expression of ICL1 is up-regulated during co-incubation with macrophages (Lorenz and Fink, 2001; Lorenz et al., 2004). Accordingly, the C. albicans $\Delta i c l 1$ mutant is less virulent in mice (Lorenz and Fink, 2001; Ramírez and Lorenz, 2007). In our amoebae plate test the $\Delta i c l 1$ mutant also showed a reduced resistance toward predation by the amoebae. This demonstrates the significance of the glyoxylate cycle in microbial pathogenesis, especially for the interaction with phagocytic cells.

C. albicans was for a long time thought to be an obligate diploid yeast, but recently it was shown that it is possible to construct stable haploid strains of $C$. albicans, facilitating the molecular and genetic analysis of this important fungal pathogen (Hickman et al., 2013). We investigated whether D. discoideum could be used in combination with haploid C. albicans strains. In contrast to a mouse model of systemic candidiasis, in which the haploid C. albicans strain tested was avirulent (Hickman et al., 2013), virulence of haploid strains was only slightly reduced in our amoebae plate test in comparison to the highly virulent diploid strain SC5314. Additionally, haploid mutant strains like GZY806 ( $\Delta h g c 1)$ showed comparable phenotypes to its diploid counterpart. Other haploid mutant strains like GZY824 ( $\Delta$ sla1) or GZY825 ( $\triangle$ ace2) showed no reduced virulence (GZY824) or were even increased in virulence (GZY825). Sla1 is involved in hyphal growth by regulating actin patch dynamics and $\Delta$ sla 1 mutants show a defective hyphal development (Reijnst et al., 2010; Zeng et al., 2012). In association with $D$. discoideum the haploid $\Delta$ sla1 mutant was still able to form (pseudo-) hyphae, which might contribute to the resistance toward predation. For the transcription factor Ace2 it has been shown that it is has different roles in filament formation depending on conditions (Kelly et al., 2004; Mulhern et al., 2006). However, under most tested conditions the $\triangle a c e 2$ mutant strain has shown hyperfilamentation, even under non-inducing conditions (Kelly et al., 2004). We also observed hyperfilamentation for the haploid $\triangle a c e 2$ strain GZY825. This might contribute to the slightly increased resistance of this strain toward predation by $D$. discoideum. Further, haploid mutant strains, for which the diploid counterparts show abnormal hyphal morphogenesis, such as the exocyst subunit Sec3 ( $\Delta \sec 3)$ (Li et al., 2007) or the plasma membrane protein Rvs167 ( $\Delta r v s 167)$ (Douglas et al., 2009), were able to form filaments in contact with $D$. discoideum, but were more susceptible toward predation. At least for the haploid $\Delta r v s 167$, this result is in accordance with the reduced virulence of its diploid counterpart (Douglas et al., 2009). The haploid C. albicans mutant strains again demonstrate that hyphae formation alone is not always sufficient to mediate resistance toward predation by phagocytic cells.

The results obtained with pathogenic $C$. albicans strains emphasize the power of $D$. discoideum as a host model system. Although $D$. discoideum is no natural host for C. albicans, the investigation of the interaction of C. albicans with $D$. discoideum might result in the identification of fundamental and evolutionary conserved fungal as well as host factors important for the interaction. 


\section{CONCLUSIONS}

The concept of amoebae as training grounds for intracellular bacterial pathogens is well established. The fact that amoebae can also be used to study the interaction with fungal pathogens has been shown for different fungi (Steenbergen et al., 2001, 2003, 2004; Chrisman et al., 2010; Araujo Gde et al., 2012; Magditch et al., 2012; Hillmann et al., 2015; Madu et al., 2015). Most of these studies used $A$. castellanii as the amoebal host. However, the advantages of $D$. discoideum as a host model are evident: (i) D. discoideum is easy to cultivate and highly amenable to genetic manipulations (Fey et al., 2007; Gaudet et al., 2007), (ii) D. discoideum has a fully sequenced genome (Eichinger et al., 2005), and (iii) a central resource platform for genome informationas well as a stock center for plasmids, mutant strains, etc.-is available (Kreppel et al., 2004; Fey et al., 2013).

We now introduce $D$. discoideum as a suitable host model to study the interaction with apathogenic and pathogenic yeast. Our modified methods allow the use of $D$. discoideum for risk assessment of various yeast strains, as well as for the investigation of host-pathogen interactions on a cellular level. Limiting factors of our methods are the relative low temperature $\left(22^{\circ} \mathrm{C}\right)$ during amoebae-fungus interaction and the fact that yeasts are not the preferred food source for $D$. discoideum, leading to overgrowth of the amoebae by non-phagocytized and nonkilled yeast during longer co-incubation. However, the details of the interaction between C. albicans and phagocytic cells like macrophages are only poorly understood (Kong and Jabra-Rizk, 2015). Investigating the interaction of pathogenic yeast with the genetically highly amenable $D$. discoideum amoebae might help to elucidate new (evolutionarily conserved) aspects of fungusphagocyte interaction. In combination with haploid C. albicans strains the amoeba might be useful to identify new virulence factors in large-scale mutagenesis methods.

\section{REFERENCES}

Abeliovich, H., Dunn, W. A. Jr., Kim, J., and Klionsky, D. J. (2000). Dissection of autophagosome biogenesis into distinct nucleation and expansion steps. J. Cell Biol. 151, 1025-1034. doi: 10.1083/jcb.151.5.1025

Akoumianaki, T., Kyrmizi, I., Valsecchi, I., Gresnigt, M. S., Samonis, G., Drakos, E., et al. (2016). Aspergillus cell wall melanin blocks LC3-associated phagocytosis to promote pathogenicity. Cell Host Microbe 19, 79-90. doi: 10.1016/j.chom.2015.12.002

Albers, U., Reus, K., Shuman, H. A., and Hilbi, H. (2005). The amoebae plate test implicates a paralogue of lpxB in the interaction of Legionella pneumophila with Acanthamoeba castellanii. Microbiology 151(Pt 1), 167-182. doi: 10.1099/mic.0.27563-0

Araujo Gde, S., Fonseca, F. L., Pontes, B., Torres, A., Cordero, R. J., Zancopé-Oliveira, R. M., et al. (2012). Capsules from pathogenic and nonpathogenic Cryptococcus spp. manifest significant differences in structure and ability to protect against phagocytic cells. PLoS ONE 7:e29561. doi: 10.1371/journal.pone.0029561

Bain, J. M., Lewis, L. E., Okai, B., Quinn, J., Gow, N. A., and Erwig, L. P. (2012). Non-lytic expulsion/exocytosis of Candida albicans from macrophages. Fungal Genet. Biol. 49, 677-678. doi: 10.1016/j.fgb.2012.01.008

Barwell, K. J., Boysen, J. H., Xu, W., and Mitchell, A. P. (2005). Relationship of DFG16 to the Rim101p pH response pathway in Saccharomyces cerevisiae
AUTHOR CONTRIBUTIONS

BK and SS carried out amoeba plate tests, growth assays, and the analysis of hyphae formation; CS and ED did amoeba plate tests and phagocytosis and killing assays, CS additionally worked with haploid C. albicans strains (including flow cytometry); JT did amoeba plate tests, the analysis of flocculation, and plaque assays; AP analyzed non-axenic Dictyostelia; VR and ST conceived the experiments and wrote the manuscript. All authors read and approved the final version of the manuscript.

\section{ACKNOWLEDGMENTS}

We want to thank B. Hube (Jena, Germany), G. Zeng (Singapore, Singapore), M. Lorenz (Houston, Texas, USA), K. Verstrepen (Leuven, Belgium), G. Gerisch (Martinsried, Germany), and the Japanese Yeast Genetic Resource Centre (Osaka, Japan) for providing yeast strains. We also thank T. Soldati, P. Cosson (both Geneva, Switzerland), T. Winckler (Jena, Germany), and the Dicty Stock Center (Chicago, Illinois, USA) for providing amoebae strains. We thank H. Schäfer and S. Gurka (both Berlin, Germany) for help with flow cytometry. Further we want to thank R. Mutzel and M. Wurm (both Berlin, Germany) for critical reading of the manuscript. We acknowledge support by the German Research Foundation and the OpenAccess Publication Funds of the Freie Universität Berlin.

\section{SUPPLEMENTARY MATERIAL}

The Supplementary Material for this article can be found online at: http://journal.frontiersin.org/article/10.3389/fmicb. 2016.01665 and Candida albicans. Eukaryot. Cell 4, 890-899. doi: 10.1128/EC.4.5.890-8 99.2005

Beauvais, A., Loussert, C., Prevost, M. C., Verstrepen, K., and Latgé, J. P. (2009). Characterization of a biofilm-like extracellular matrix in FLO1-expressing Saccharomyces cerevisiae cells. FEMS Yeast Res. 9, 411-419. doi: 10.1111/j.15671364.2009.00482.x

Benghezal, M., Cornillon, S., Gebbie, L., Alibaud, L., Brückert, F., Letourneur, F., et al. (2003). Synergistic control of cellular adhesion by transmembrane 9 proteins. Mol. Biol. Cell 14, 2890-2899. doi: 10.1091/mbc.E02-1 1-0724

Benghezal, M., Fauvarque, M. O., Tournebize, R., Froquet, R., Marchetti, A., Bergeret, E., et al. (2006). Specific host genes required for the killing of Klebsiella bacteria by phagocytes. Cell. Microbiol. 8, 139-148. doi: 10.1111/j.14625822.2005.00607.x

Bloomfield, G., Traynor, D., Sander, S. P., Veltman, D. M., Pachebat, J. A., and Kay, R. R. (2015). Neurofibromin controls macropinocytosis and phagocytosis in Dictyostelium. Elife 4:e04940. doi: 10.7554/eLife.04940

Boeckeler, K., Tischendorf, G., Mutzel, R., and Weissenmayer, B. (2006). Aberrant stalk development and breakdown of tip dominance in Dictyostelium cell lines with RNAi-silenced expression of calcineurin B. BMC Dev. Biol. 6:12. doi: 10.1186/1471-213X-6-12

Bozzaro, S. (2013). The model organism Dictyostelium discoideum. Methods Mol. Biol. 983, 17-37. doi: 10.1007/978-1-62703-302-2_2 
Bozzaro, S., and Eichinger, L. (2011). The professional phagocyte Dictyostelium discoideum as a model host for bacterial pathogens. Curr. Drug Targets 12, 942-954. doi: 10.2174/138945011795677782

Brefeld, O. (1869). Dictyostelium mucoroides. Ein neuer Organismus aus der Verwandtschaft der Myxomyceten. Abhandlungen der Senckenbergischen Naturforschenden Gesellschaft Frankfurt 7, 85-107.

Carnell, M., Zech, T., Calaminus, S. D., Ura, S., Hagedorn, M., Johnston, S. A., et al. (2011). Actin polymerization driven by WASH causes V-ATPase retrieval and vesicle neutralization before exocytosis. J. Cell Biol. 193, 831-839. doi: $10.1083 /$ jcb. 201009119

Caterina, M. J., Milne, J. L., and Devreotes, P. N. (1994). Mutation of the third intracellular loop of the cAMP receptor, cAR1, of Dictyostelium yields mutants impaired in multiple signaling pathways. J. Biol. Chem. 269, 1523-1532.

Chang, W. T., Thomason, P. A., Gross, J. D., and Neweil, P. C. (1998). Evidence that the RdeA protein is a component of a multistep phosphorelay modulating rate of development in Dictyostelium. EMBO J. 17, 2809-2816. doi: 10.1093/emboj/17.10.2809

Chrisman, C. J., Albuquerque, P., Guimaraes, A. J., Nieves, E., and Casadevall, A. (2011). Phospholipids trigger Cryptococcus neoformans capsular enlargement during interactions with amoebae and macrophages. PLoS Pathog. 7:e1002047. doi: 10.1371/journal.ppat.1002047

Chrisman, C. J., Alvarez, M., and Casadevall, A. (2010). Phagocytosis of Cryptococcus neoformans by, and nonlytic exocytosis from, Acanthamoeba castellanii. Appl. Environ. Microbiol. 76, 6056-6062. doi: 10.1128/AEM. 00812-10

Clarke, M. (2010). Recent insights into host-pathogen interactions from Dictyostelium. Cell. Microbiol. 12, 283-291. doi: 10.1111/j.14625822.2009.01413.x

Clemons, K. V., Hanson, L. C., and Stevens, D. A. (1996). Colony phenotype switching in clinical and non-clinical isolates of Saccharomyces cerevisiae. J. Med. Vet. Mycol. 34, 259-264.

Cornillon, S., Gebbie, L., Benghezal, M., Nair, P., Keller, S., Wehrle-Haller, B., et al. (2006). An adhesion molecule in free-living Dictyostelium amoebae with integrin beta features. EMBO Rep. 7, 617-621. doi: 10.1038/sj.embor. 7400701

Cornillon, S., Pech, E., Benghezal, M., Ravanel, K., Gaynor, E., Letourneur, F., et al. (2000). Phglp is a nine-transmembrane protein superfamily member involved in dictyostelium adhesion and phagocytosis. J. Biol. Chem. 275, 34287-34292. doi: 10.1074/jbc.M006725200

Deretic, V., Saitoh, T., and Akira, S. (2013). Autophagy in infection, inflammation and immunity. Nat. Rev. Immunol. 13, 722-737. doi: 10.1038/nri3532

Diezmann, S., and Dietrich, F. S. (2009). Saccharomyces cerevisiae: population divergence and resistance to oxidative stress in clinical, domesticated and wild isolates. PLoS ONE 4:e5317. doi: 10.1371/journal.pone.0005317

Douglas, L. M., Martin, S. W., and Konopka, J. B. (2009). BAR domain proteins Rvs161 and Rvs167 contribute to Candida albicans endocytosis, morphogenesis, and virulence. Infect. Immun. 77, 4150-4160. doi: 10.1128/IAI.00683-09

Du, Q., Kawabe, Y., Schilde, C., Chen, Z. H., and Schaap, P. (2015). The evolution of aggregative multicellularity and cell-cell communication in the dictyostelia. J. Mol. Biol. 427, 3722-3733. doi: 10.1016/j.jmb.2015.08.008

Eichinger, L., Pachebat, J. A., Glöckner, G., Rajandream, M. A., Sucgang, R., Berriman, M., et al. (2005). The genome of the social amoeba Dictyostelium discoideum. Nature 435, 43-57. doi: 10.1038/nature03481

Fey, P., Dodson, R. J., Basu, S., and Chisholm, R. L. (2013). One stop shop for everything Dictyostelium: dictyBase and the Dicty Stock Center in 2012. Methods Mol. Biol. 983, 59-92. doi: 10.1007/978-1-62703-302-2_4

Fey, P., Kowal, A. S., Gaudet, P., Pilcher, K. E., and Chisholm, R. L. (2007). Protocols for growth and development of Dictyostelium discoideum. Nat. Protoc. 2, 1307-1316. doi: 10.1038/nprot.2007.178

Fonzi, W. A., and Irwin, M. Y. (1993). Isogenic strain construction and gene mapping in Candida albicans. Genetics 134, 717-728.

Fradin, C., De Groot, P., MacCallum, D., Schaller, M., Klis, F., Odds, F. C., et al. (2005). Granulocytes govern the transcriptional response, morphology and proliferation of Candida albicans in human blood. Mol. Microbiol. 56, 397-415. doi: $10.1111 / j .1365-2958.2005 .04557$

Francis, D. (1975). Cyclic AMP-induced changes in protein synthesis in a cellular slime mould, Polysphondylium pallidum. Nature 258, 763-765.
Froquet, R., Lelong, E., Marchetti, A., and Cosson, P. (2009). Dictyostelium discoideum: a model host to measure bacterial virulence. Nat. Protoc. 4, 25-30. doi: 10.1038/nprot.2008.212

Gaudet, P., Pilcher, K. E., Fey, P., and Chisholm, R. L. (2007). Transformation of Dictyostelium discoideum with plasmid DNA. Nat. Protoc. 2, 1317-1324. doi: 10.1038/nprot.2007.179

Gerstenmaier, L., Pilla, R., Herrmann, L., Herrmann, H., Prado, M., Villafano, G. J., et al. (2015). The autophagic machinery ensures nonlytic transmission of mycobacteria. Proc. Natl. Acad. Sci. U.S.A. 112, E687-E692. doi: 10.1073/pnas. 1423318112

Gillum, A. M., Tsay, E. Y., and Kirsch, D. R. (1984). Isolation of the Candida albicans gene for orotidine- $5^{\prime}$-phosphate decarboxylase by complementation of S. cerevisiae ura3 and E. coli pyrF mutations. Mol. Gen. Genet. 198, 179-182.

Gopaldass, N., Patel, D., Kratzke, R., Dieckmann, R., Hausherr, S., Hagedorn, M., et al. (2012). Dynamin A, Myosin IB and Abp1 couple phagosome maturation to F-actin binding. Traffic 13, 120-130. doi: 10.1111/j.1600-0854.2011.01296.x

Guinea, J. (2014). Global trends in the distribution of Candida species causing candidemia. Clin. Microbiol. Infect. 20(Suppl. 6), 5-10. doi: 10.1111/14690691.12539

Harper, J. W., Adami, G. R., Wei, N., Keyomarsi, K., and Elledge, S. J. (1993). The p21 Cdk-interacting protein Cip1 is a potent inhibitor of G1 cyclin-dependent kinases. Cell 75, 805-816.

Hickman, M. A., Zeng, G., Forche, A., Hirakawa, M. P., Abbey, D., Harrison, B. D., et al. (2013). The 'obligate diploid' Candida albicans forms mating-competent haploids. Nature 494, 55-59. doi: 10.1038/nature1 1865

Hillmann, F., Novohradská, S., Mattern, D. J., Forberger, T., Heinekamp, T., Westermann, M., et al. (2015). Virulence determinants of the human pathogenic fungus Aspergillus fumigatus protect against soil amoeba predation. Environ. Microbiol. 17, 2858-2869. doi: 10.1111/1462-2920.12808

Jia, K., Thomas, C., Akbar, M., Sun, Q., Adams-Huet, B., Gilpin, C., et al. (2009). Autophagy genes protect against Salmonella typhimurium infection and mediate insulin signaling-regulated pathogen resistance. Proc. Natl. Acad. Sci. U.S.A. 106, 14564-14569. doi: 10.1073/pnas.0813319106

Kanayama, M., Inoue, M., Danzaki, K., Hammer, G., He, Y. W., and Shinohara, M. L. (2015). Autophagy enhances NF $\kappa$ B activity in specific tissue macrophages by sequestering A20 to boost antifungal immunity. Nat. Commun. 6:5779. doi: $10.1038 /$ ncomms6779

Kelly, M. T., MacCallum, D. M., Clancy, S. D., Odds, F. C., Brown, A. J., and Butler, G. (2004). The Candida albicans CaACE2 gene affects morphogenesis, adherence and virulence. Mol. Microbiol. 53, 969-983. doi: 10.1111/j.13652958.2004.04185.x

Keppler-Ross, S., Douglas, L., Konopka, J. B., and Dean, N. (2010). Recognition of yeast by murine macrophages requires mannan but not glucan. Eukaryot. Cell 9, 1776-1787. doi: 10.1128/EC.00156-10

Kong, E., and Jabra-Rizk, M. A. (2015). The great escape: pathogen versus host. PLoS Pathog. 11:e1004661. doi: 10.1371/journal.ppat.1004661

Kreppel, L., Fey, P., Gaudet, P., Just, E., Kibbe, W. A., Chisholm, R. L., et al. (2004). dictyBase: a new Dictyostelium discoideum genome database. Nucleic Acids Res. 32, D332-D333. doi: 10.1093/nar/gkh138

Kretschmar, M., Felk, A., Staib, P., Schaller, M., Hess, D., Callapina, M., et al. (2002). Individual acid aspartic proteinases (Saps) 1-6 of Candida albicans are not essential for invasion and colonization of the gastrointestinal tract in mice. Microb. Pathog. 32, 61-70. doi: 10.1006/mpat.2001.0478

Kretschmar, M., Hube, B., Bertsch, T., Sanglard, D., Merker, R., Schröder, M., et al. (1999). Germ tubes and proteinase activity contribute to virulence of Candida albicans in murine peritonitis. Infect. Immun. 67, 6637-6642.

Lampe, E. O., Brenz, Y., Herrmann, L., Repnik, U., Griffiths, G., Zingmark, C., et al. (2016). Dissection of Francisella-host cell interactions in Dictyostelium discoideum. Appl. Environ. Microbiol. 82, 1586-1598. doi: 10.1128/AEM. 02950-15

Le Coadic, M., Froquet, R., Lima, W. C., Dias, M., Marchetti, A., and Cosson, P. (2013). Phg1/TM9 proteins control intracellular killing of bacteria by determining cellular levels of the Kil1 sulfotransferase in Dictyostelium. PLoS ONE 8:e53259. doi: 10.1371/journal.pone.0053259

Lelong, E., Marchetti, A., Guého, A., Lima, W. C., Sattler, N., Molmeret, M., et al. (2011). Role of magnesium and a phagosomal P-type ATPase in intracellular bacterial killing. Cell. Microbiol. 13, 246-258. doi: 10.1111/j.14625822.2010.01532.x 
Lenz, H. D., Haller, E., Melzer, E., Kober, K., Wurster, K., Stahl, M., et al. (2011). Autophagy differentially controls plant basal immunity to biotrophic and necrotrophic pathogens. Plant J. 66, 818-830. doi: 10.1111/j.1365313X.2011.04546.X

Lewis, L. E., Bain, J. M., Lowes, C., Gillespie, C., Rudkin, F. M., Gow, N. A., et al. (2012). Stage specific assessment of Candida albicans phagocytosis by macrophages identifies cell wall composition and morphogenesis as key determinants. PLoS Pathog. 8:e1002578. doi: 10.1371/journal.ppat.1002578

Li, C. R., Lee, R. T., Wang, Y. M., Zheng, X. D., and Wang, Y. (2007). Candida albicans hyphal morphogenesis occurs in Sec3p-independent and Sec3pdependent phases separated by septin ring formation. J. Cell Sci. 120(Pt 11), 1898-1907. doi: $10.1242 /$ jcs.002931

Liu, H., Köhler, J., and Fink, G. R. (1994). Suppression of hyphal formation in Candida albicans by mutation of a STE12 homolog. Science 266, 1723-1726.

Lo, H. J., Köhler, J. R., DiDomenico, B., Loebenberg, D., Cacciapuoti, A., and Fink, G. R. (1997). Nonfilamentous C. albicans mutants are avirulent. Cell 90, 939-949.

Lorenz, M. C., Bender, J. A., and Fink, G. R. (2004). Transcriptional response of Candida albicans upon internalization by macrophages. Eukaryot. Cell 3, 1076-1087. doi: 10.1128/EC.3.5.1076-1087.2004

Lorenz, M. C., and Fink, G. R. (2001). The glyoxylate cycle is required for fungal virulence. Nature 412, 83-86. doi: 10.1038/35083594

Lu, Y., Su, C., and Liu, H. (2014). Candida albicans hyphal initiation and elongation. Trends Microbiol. 22, 707-714. doi: 10.1016/j.tim.2014.09.001

Ma, H., Croudace, J. E., Lammas, D. A., and May, R. C. (2006). Expulsion of live pathogenic yeast by macrophages. Curr. Biol. 16, 2156-2160. doi: 10.1016/j.cub.2006.09.032

Madu, U. L., Ogundeji, A. O., Mochochoko, B. M., Pohl, C. H., Albertyn, J., Swart, C. W., et al. (2015). Cryptococcal 3-Hydroxy fatty acids protect cells against amoebal phagocytosis. Front. Microbiol. 6:1351. doi: 10.3389/fmicb.2015.01351

Magditch, D. A., Liu, T. B., Xue, C., and Idnurm, A. (2012). DNA mutations mediate microevolution between host-adapted forms of the pathogenic fungus Cryptococcus neoformans. PLoS Pathog. 8:e1002936. doi: 10.1371/journal.ppat.1002936

Mattern, D. J., Schoeler, H., Weber, J., Novohradská, S., Kraibooj, K., Dahse, H. M., et al. (2015). Identification of the antiphagocytic trypacidin gene cluster in the human-pathogenic fungus Aspergillus fumigatus. Appl. Microbiol. Biotechnol. 99, 10151-10161. doi: 10.1007/s00253-015-6898-1

McCusker, J. H., Clemons, K. V., Stevens, D. A., and Davis, R. W. (1994). Saccharomyces cerevisiae virulence phenotype as determined with CD-1 mice is associated with the ability to grow at 42 degrees $\mathrm{C}$ and form pseudohyphae. Infect. Immun. 62, 5447-5455.

McKenzie, C. G., Koser, U., Lewis, L. E., Bain, J. M., Mora-Montes, H. M., Barker, R. N., et al. (2010). Contribution of Candida albicans cell wall components to recognition by and escape from murine macrophages. Infect. Immun. 78, 1650-1658. doi: 10.1128/IAI.00001-10

Mulhern, S. M., Logue, M. E., and Butler, G. (2006). Candida albicans transcription factor Ace2 regulates metabolism and is required for filamentation in hypoxic conditions. Eukaryot. Cell 5, 2001-2013. doi: 10.1128/EC.00155-06

Murad, A. M., Lee, P. R., Broadbent, I. D., Barelle, C. J., and Brown, A. J. (2000). CIp10, an efficient and convenient integrating vector for Candida albicans. Yeast 16, 325-327. doi: 10.1002/1097-0061(20000315)16:4<325::AIDYEA538>3.0.CO;2-

Müller-Taubenberger, A., Kortholt, A., and Eichinger, L. (2013). Simple systemsubstantial share: the use of Dictyostelium in cell biology and molecular medicine. Eur. J. Cell Biol. 92, 45-53. doi: 10.1016/j.ejcb.2012.10.003

Nicola, A. M., Albuquerque, P., Martinez, L. R., Dal-Rosso, R. A., Saylor, C., De Jesus, M., et al. (2012). Macrophage autophagy in immunity to Cryptococcus neoformans and Candida albicans. Infect. Immun. 80, 3065-3076. doi: 10.1128/IAI.00358-12

Nonklang, S., Ano, A., Abdel-Banat, B. M., Saito, Y., Hoshida, H., and Akada, R. (2009). Construction of flocculent Kluyveromyces marxianus strains suitable for high-temperature ethanol fermentation. Biosci. Biotechnol. Biochem. 73, 1090-1095. doi: 10.1271/bbb.80853

Otto, G. P., Wu, M. Y., Kazgan, N., Anderson, O. R., and Kessin, R. H. (2003). Macroautophagy is required for multicellular development of the social amoeba Dictyostelium discoideum. J. Biol. Chem. 278, 17636-17645. doi: 10.1074/jbc.M212467200
Otto, G. P., Wu, M. Y., Kazgan, N., Anderson, O. R., and Kessin, R. H. (2004). Dictyostelium macroautophagy mutants vary in the severity of their developmental defects. J. Biol. Chem. 279, 15621-15629. doi: 10.1074/jbc.M311139200

Purevdorj-Gage, B., Orr, M. E., Stoodley, P., Sheehan, K. B., and Hyman, L. E. (2007). The role of FLO11 in Saccharomyces cerevisiae biofilm development in a laboratory based flow-cell system. FEMS Yeast Res. 7, 372-379. doi: 10.1111/j.1567-1364.2006.00189.x

Qin, Q. M., Luo, J., Lin, X., Pei, J., Li, L., Ficht, T. A., et al. (2011). Functional analysis of host factors that mediate the intracellular lifestyle of Cryptococcus neoformans. PLoS Pathog. 7:e1002078. doi: 10.1371/journal.ppat. 1002078

Ramírez, M. A., and Lorenz, M. C. (2007). Mutations in alternative carbon utilization pathways in Candida albicans attenuate virulence and confer pleiotropic phenotypes. Eukaryot. Cell 6, 280-290. doi: 10.1128/EC. 00372-06

Reijnst, P., Jorde, S., and Wendland, J. (2010). Candida albicans SH3-domain proteins involved in hyphal growth, cytokinesis, and vacuolar morphology. Curr. Genet. 56, 309-319. doi: 10.1007/s00294-010-0301-7

Rivero, F., and Maniak, M. (2006). Quantitative and microscopic methods for studying the endocytic pathway. Methods Mol. Biol. 346, 423-438. doi: 10.1385/1-59745-144-4:423

Rosentul, D. C., Plantinga, T. S., Farcas, M., Oosting, M., Hamza, O. J., Scott, W. $\mathrm{K}$., et al. (2014). Role of autophagy genetic variants for the risk of Candida infections. Med. Mycol. 52, 333-341. doi: 10.1093/mmy/myt035

Sanglard, D., Hube, B., Monod, M., Odds, F. C., and Gow, N. A. (1997). A triple deletion of the secreted aspartyl proteinase genes SAP4, SAP5, and SAP6 of Candida albicans causes attenuated virulence. Infect. Immun. 65, 3539-3546.

Schaap, P., Winckler, T., Nelson, M., Alvarez-Curto, E., Elgie, B., Hagiwara, H., et al. (2006). Molecular phylogeny and evolution of morphology in the social amoebas. Science 314, 661-663. doi: 10.1126/science.1130670

Smeekens, S. P., Malireddi, R. K., Plantinga, T. S., Buffen, K., Oosting, M., Joosten, L. A., et al. (2014). Autophagy is redundant for the host defense against systemic Candida albicans infections. Eur. J. Clin. Microbiol. Infect. Dis. 33, 711-722. doi: 10.1007/s10096-013-2002-x

Smukalla, S., Caldara, M., Pochet, N., Beauvais, A., Guadagnini, S., Yan, C., et al. (2008). FLO1 is a variable green beard gene that drives biofilm-like cooperation in budding yeast. Cell 135, 726-737. doi: 10.1016/j.cell.2008.09.037

Somesh, B. P., Neffgen, C., Iijima, M., Devreotes, P., and Rivero, F. (2006). Dictyostelium $\mathrm{RacH}$ regulates endocytic vesicular trafficking and is required for localization of vacuolin. Traffic 7, 1194-1212. doi: 10.1111/j.16000854.2006.00455.x

Steenbergen, J. N., Nosanchuk, J. D., Malliaris, S. D., and Casadevall, A. (2003). Cryptococcus neoformans virulence is enhanced after growth in the genetically malleable host Dictyostelium discoideum. Infect. Immun. 71, 4862-4872. doi: 10.1128/IAI.71.9.4862-4872.2003

Steenbergen, J. N., Nosanchuk, J. D., Malliaris, S. D., and Casadevall, A. (2004). Interaction of Blastomyces dermatitidis, Sporothrix schenckii, and Histoplasma capsulatum with Acanthamoeba castellanii. Infect. Immun. 72, 3478-3488. doi: 10.1128/IAI.72.6.3478-3488.2004

Steenbergen, J. N., Shuman, H. A., and Casadevall, A. (2001). Cryptococcus neoformans interactions with amoebae suggest an explanation for its virulence and intracellular pathogenic strategy in macrophages. Proc. Natl. Acad. Sci. U.S.A. 98, 15245-15250. doi: 10.1073/pnas.261418798

Thewes, S., Kretschmar, M., Park, H., Schaller, M., Filler, S. G., and Hube, B. (2007). In vivo and ex vivo comparative transcriptional profiling of invasive and non-invasive Candida albicans isolates identifies genes associated with tissue invasion. Mol. Microbiol. 63, 1606-1628. doi: 10.1111/j.1365-2958.2007. 05614.x

Thewes, S., Moran, G. P., Magee, B. B., Schaller, M., Sullivan, D. J., and Hube, B. (2008). Phenotypic screening, transcriptional profiling, and comparative genomic analysis of an invasive and non-invasive strain of Candida albicans. BMC Microbiol. 8:187. doi: 10.1186/1471-2180-8-187

Thewes, S., Schubert, S. K., Park, K., and Mutzel, R. (2014). Stress and development in Dictyostelium discoideum: the involvement of the catalytic calcineurin A subunit. J. Basic Microbiol. 54, 607-613. doi: 10.1002/jobm.201200574

Tosetti, N., Croxatto, A., and Greub, G. (2014). Amoebae as a tool to isolate new bacterial species, to discover new virulence factors and to 
study the host-pathogen interactions. Microb. Pathog. 77, 125-130. doi: 10.1016/j.micpath.2014.07.009

Verstrepen, K. J., Derdelinckx, G., Verachtert, H., and Delvaux, F. R. (2003). Yeast flocculation: what brewers should know. Appl. Microbiol. Biotechnol. 61, 197-205. doi: 10.1007/s00253-002-1200-8

Wallis, J. W., Chrebet, G., Brodsky, G., Rolfe, M., and Rothstein, R. (1989). A hyper-recombination mutation in $S$. cerevisiae identifies a novel eukaryotic topoisomerase. Cell 58, 409-419.

Watts, D. J., and Ashworth, J. M. (1970). Growth of myxameobae of the cellular slime mould Dictyostelium discoideum in axenic culture. Biochem. J. 119, $171-174$.

Wienke, D. C., Knetsch, M. L., Neuhaus, E. M., Reedy, M. C., and Manstein, D. J. (1999). Disruption of a dynamin homologue affects endocytosis, organelle morphology, and cytokinesis in Dictyostelium discoideum. Mol. Biol. Cell 10, 225-243.

Winchell, C. G., Steele, S., Kawula, T., and Voth, D. E. (2016), Dining in: intracellular bacterial pathogen interplay with autophagy. Curr. Opin. Microbiol. 29, 9-14. doi: 10.1016/j.mib.2015. 09.004

Witkin, E. M. (1946). Inherited differences in sensitivity to radiation in Escherichia Coli. Proc. Natl. Acad. Sci. U.S.A. 32, 59-68.
Woznica, D., and Knecht, D. A. (2006). Under-agarose chemotaxis of Dictyostelium discoideum. Methods Mol. Biol. 346, 311-325. doi: 10.1385/159745-144-4:311

Zeng, G., Wang, Y. M., and Wang, Y. (2012). Cdc28-Cln3 phosphorylation of Sla1 regulates actin patch dynamics in different modes of fungal growth. Mol. Biol. Cell 23, 3485-3497. doi: 10.1091/mbc.E12-03-0231

Zheng, X., Wang, Y., and Wang, Y. (2004). Hgc1, a novel hypha-specific G1 cyclinrelated protein regulates Candida albicans hyphal morphogenesis. EMBO J. 23, 1845-1856. doi: 10.1038/sj.emboj.7600195

Conflict of Interest Statement: The authors declare that the research was conducted in the absence of any commercial or financial relationships that could be construed as a potential conflict of interest.

Copyright (C) 2016 Koller, Schramm, Siebert, Triebel, Deland, Pfefferkorn, Rickerts and Thewes. This is an open-access article distributed under the terms of the Creative Commons Attribution License (CC BY). The use, distribution or reproduction in other forums is permitted, provided the original author(s) or licensor are credited and that the original publication in this journal is cited, in accordance with accepted academic practice. No use, distribution or reproduction is permitted which does not comply with these terms. 